\title{
Antimicrobial peptide 17BIPHE2 inhibits the proliferation of lung cancer cells in vitro and in vivo by regulating the ERK signaling pathway
}

\author{
TINGTING YANG ${ }^{1 *}$, JUN LI $^{2 *}$, QINQIN JIA ${ }^{3 *}$, SHISHENG ZHAN ${ }^{4}$, \\ QIANNAN ZHANG ${ }^{5}$, YARONG WANG ${ }^{6}$ and XIUQING WANG ${ }^{5}$
}

\begin{abstract}
${ }^{1}$ Department of Clinical Laboratory, Yinchuan Maternal and Child Health Care Hospital, Yinchuan, Ningxia Hui Autonomous Region 750004; ${ }^{2}$ Department of Clinical Laboratory, Tangshan Gongren Hospital, Tangshan, Hebei 063000; ${ }^{3}$ Department of Laboratory Medicine, Health Center, Chun Rong, Gansu 745211; ${ }^{4}$ Department of Clinical Laboratory, Hebei Yanda Lu Daopei Hospital, Langfang, Hebei 065200; ${ }^{5}$ Department of Laboratory Medicine, College of Clinical Medicine, Shuangyi Campus, Ningxia Medical University, Yinchuan, Ningxia Hui Autonomous Region 750004; ${ }^{6}$ Department of Pathology, Institute of Hematology and Blood Diseases Hospital, Chinese Academy of Medical Sciences, Tianjin 300020, P.R. China
\end{abstract}

Received June 24, 2020; Accepted February 24, 2021

DOI: $10.3892 / 01.2021 .12762$

\begin{abstract}
In 2018, there were 18.1 million new cancer cases and 9.6 million cancer-related deaths worldwide, among which the incidence rate of lung cancer $(11.6 \%)$ and fatality rate (18.4\%) both ranked first. The antimicrobial peptide LL-37 is an important component of the natural immune system and possesses several biological properties, including antibacterial, antiviral and anticancer effects. The antimicrobial peptide 17BIPHE2, the shortest synthetic peptide derivative of LL-37, exhibits biological activities similar to those of LL-37. The objective of the present study was to investigate the mechanism of action of exogenous 17BIPHE2 against lung cancer cells. The human lung adenocarcinoma cell line A549 was treated with 17BIPHE2. Changes in cell proliferation, migration, invasion, mitochondrial membrane potential $(\Delta \Psi \mathrm{m})$, and the levels of reactive oxygen species (ROS), $\mathrm{Ca}^{2+}$ and apoptosis-related proteins, including BAX, BCL-2 and ERK, were detected using flow cytometry, transmission electron microscopy and western blotting. The results showed that 17BIPHE2 significantly increased the apoptosis rate of A549 cells and elevated BAX expression, ERK phosphorylation, and
\end{abstract}

Correspondence to: Dr Xiuqing Wang, Department of Laboratory Medicine, College of Clinical Medicine, Shuangyi Campus, Ningxia Medical University, 692 Shengli Street, Xingqing, Yinchuan, Ningxia Hui Autonomous Region 750004, P.R. China

E-mail: xiuqingwang1979@163.com

*Contributed equally

Key words: antimicrobial peptide, 17BIPHE2, apoptosis, lung adenocarcinoma, A549 cells
ROS and $\mathrm{Ca}^{2+}$ levels, but decreased the expression of BCL-2, ERK and Ki67. In addition, the peptide reduced $\Delta \Psi \mathrm{m}$ and the cell migration ability of A549 cells and inhibited tumor growth. ERK inhibition significantly attenuated the anticancer effect of 17BIPHE2. The present observations suggested that 17BIPHE2 can effectively inhibit cancer cells by regulating the ERK signaling pathway.

\section{Introduction}

Lung cancer is the most common type of cancer with a survival time of $<5$ years and is one of the main causes of cancer-associated death worldwide $(1,2)$. Although chemotherapy and radiotherapy have clearly improved the prognosis, these treatments cannot be applied for a long time owing to adverse effects on the human body. Therefore, new antitumor drugs are needed for treating lung cancer. Human cathelicidin (hCAP)-18/LL-37 has attracted much attention due to its role in regulating the release of proinflammatory factors in the lung innate and adaptive immune system (3).

The LL-37 peptide, named for its 37 amino acids, has antitumor and antimicrobial effects. A previous study showed that the antimicrobial peptide LL-37 can exerting antitumor effects both in vitro and in vivo (4). Thus, LL-37 is a promising antitumor drug candidate. LL-37 can be divided into functional components that have different roles, which possess antibacterial, antitumor, antiparasitic and antiviral properties. The antimicrobial peptide 17BIPHE2, the shortest of the LL-37-derived peptides, was designed and synthesized by Professor Guangshun Wang of the Nebraska Medical Center (5). The amino acid sequence of this peptide is GBKRLVQRLKDBLRNLV (6). Previously we have shown that the 17BIPHE2 can effectively inhibit the proliferation and biofilm formation of methicillin-resistant staphylococcus aureus by disrupting the integrity of microbial membranes (7). 
However, whether the novel synthetic drug can inhibit tumors is unknown, and the mechanism by which 17BIPHE2 exerts its anticancer effect is not completely understood.

ERK is a serine/threonine protein kinase that is widely present in eukaryotic cells and belongs to the MAPK family of proteins. The ERK signaling pathway affects cell proliferation, invasion and migration (8). A study has shown that phosphorylated (p-)ERK can mediate apoptosis in pancreatic cancer cells by regulating the ratio of BAX/BCL-2 (9). Studies have also showed that ERK controls colorectal tumor cell apoptosis by regulating the expression of BAX and BCL-2 $(8,10)$.

In our previous studies, we reported that 17BIPHE2 peptide can inhibit the formation of biofilms of Staphylococcus aureus and Pseudomonas aeruginosa, and 17BIPHE2 peptide is superior to LL-37 due to reduced cell hemolysis and quality guarantee in artificial synthesis. Non-small cell lung cancer (NSCLC) accounts for $>85 \%$ of lung cancer cases (11), and studies on the effect of 17BIPHE2 on lung cancer cells have not yet been performed to the best of our knowledge. A series of relevant experiments were conducted to investigate the effect of the 17BIPHE2 peptide against the human lung adenocarcinoma cell line, A549, and identified novel mechanisms by which 17BIPHE2 induced apoptosis in these cells. The effects of 17BIPHE2 on tumor biology, including proliferation, chemotaxis, invasiveness and changes in the expression levels of related genes and proteins were also investigated. The results may assist in the development of a novel promising anticancer drug that can be used as an alternative therapy for lung cancer with lower toxicity and resistance and higher safety and efficiency.

\section{Materials and methods}

Cell culture. The human lung adenocarcinoma cancer cell line A549 was kindly supplied by the Affiliated Hospital of the Ningxia Medical University (The Cell Bank of Type Culture Collection of The Chinese Academy of Sciences). The lung cancer cell line NCI-H1975 and the normal human lung epithelial cell line BEAS-2B were purchased from the BeNa Culture Collection. A549 cells were cultured in in Roswell Park Memorial Institute (RPMI)-1640 medium (Hyclone; Cyvita) and NCI-H1975 cells were cultured in Dulbecco's modified Eagle's medium (Hyclone; Cyvita). BEAS-2B cells was cultured in F12K medium (Gibco; Thermo Fisher Scientific, Inc.). All cells were supplemented with $10 \%$ FBS, $100 \mathrm{U} / \mathrm{ml}$ penicillin and streptomycin (all Gibco; Thermo Fisher Scientific, Inc.). The A549 cells were cultured at $37^{\circ} \mathrm{C}$ in a cell culture incubator with $5 \% \mathrm{CO}_{2}$. Phosphate-buffered saline (PBS) and L-glutamine (Biological Industries) were used to wash cells. The cells were cultured in $25-\mathrm{cm}$ plates and passaged once every 1-2 days after a 1:3 split. All cell lines were used for experiments within 50 passages after thawing.

Synthesis and characterization of 17BIPHE2. The LL-37 peptide contains 37 amino acids, with two leucine residues at the N-terminus (6). Previously, Professor Guangshun Wang identified the minimum sequence responsible for the antimicrobial effect of LL-37 from peptide activity assays to be the 17-29th or 18-29th amino acids of LL-37 (amino acid sequence: GBKRLVQRLKDBLRNLV. RI-10 is a random control peptide with an amino acid sequence of RIVQRIKDFL derived from LL-37 (5). Solid-phase chemistry was used to synthesize the peptides with $\geq 95 \%$ purity.

Cytotoxicity of 17BIPHE2. Exponentially proliferating A549, NCI-H1975 and BEAS-2B cells were harvested from 96-well plates, and $5 \times 10^{3}$ cells/well were seeded in 96-well plates and cultured overnight at $37^{\circ} \mathrm{C}$. The cells were treated with 0,5 , $10,15,20,25,30,35$ and $40 \mu \mathrm{mol} / 1$ 17BIPHE2 and RI-10 for $24 \mathrm{~h}$ (treatment group) respectively. 17BIPHE2 (1:10 solved in $\mathrm{ddH}_{2} \mathrm{O}$ ) was not added to the control group, and no cells were added in the blank group. In total, four duplicate wells were used per group. After culturing for $24 \mathrm{~h}$, the medium in the 96-well plate was removed; then, $50 \mu \mathrm{l}$ MTT (5 g/l; Nanjing KeyGen Biotech Co., Ltd.) solution was added, and the cells were incubated in a cell culture incubator at $37^{\circ} \mathrm{C}$. After $4 \mathrm{~h}$, $150 \mu 1$ dimethyl sulfoxide (DMSO) was added to each well and the plate was left to stand at room temperature. After reaction for $10 \mathrm{~min}$, the absorbance at $490 \mathrm{~nm}$ was measured using a multiscan microplate reader (Thermo Fisher Scientific, Inc.). Percentage cell viability was calculated as follows: Cell viability $\%=[($ A treatment-blank $) /($ A control-A blank $)] \times 100 \%$, where $\mathrm{A}$ is the absorbance. The experiment was conducted in triplicate.

Cell cycle detection using flow cytometry. A549 cells in the exponential growth phase were collected after trypsinization, resuspended in RPMI-1640 culture medium and seeded in a six-well plate to obtain $1 \times 10^{8}$ cells/well. The cells were cultured in $37^{\circ} \mathrm{C}$ incubator for $24 \mathrm{~h}$ and treated with 0,25 and $35 \mu \mathrm{mol} / 1$ 17BIPHE2 for $24 \mathrm{~h}$ at $37^{\circ} \mathrm{C}$. The cells in the non-treated group were used as the control. The cells were digested with $0.25 \%$ trypsin without EDTA after 17BIPHE2 treatment. The A549 cells were washed twice with PBS for 5 min each and then fixed with pre-cooled $70 \%$ ethanol (Hyclone; Cyvita) for $2 \mathrm{~h}$ at $4^{\circ} \mathrm{C}$. The supernatant was removed via centrifugation at $800 \mathrm{x} \mathrm{g}$ and $4^{\circ} \mathrm{C}$ for $5 \mathrm{~min}$, and the pellet was washed twice with PBS, followed by the addition of $100 \mu 1 \mathrm{RNaseA}$ and incubation in a water bath at $37^{\circ} \mathrm{C}$ for $30 \mathrm{~min}$. Subsequently, $400 \mu \mathrm{l}$ propidium iodide (PI) was added, and the cell suspension was incubated at $4^{\circ} \mathrm{C}$ for $30 \mathrm{~min}$ in the dark, followed by treatment with the Cell Cycle Detection kit (Nanjing KeyGen Biotech Co., Ltd.) according to the manufacturer's instructions. Finally, the cells were detected using flow cytometry (Accuri C6; BD Biosciences) and FlowJo X version 10.0.7 (BD Biosciences) was used to analyze the data.

Detection of cellular ultrastructure. The A549 cells were subcultured in $25-\mathrm{cm}$ plates at a density of $5 \times 10^{6}$ cells/well and treated with 0,25 and $35 \mu \mathrm{mol} / 1$ 17BIPHE2 for $24 \mathrm{~h}$. Then, the medium was discarded and the cells were rinsed thrice with PBS and detached using trypsin with $0.25 \%$ EDTA (Beijing Solarbio Science \& Technology) in PBS, Afterward, the cells were, collected, and fixed for $2 \mathrm{~h}$ at $4^{\circ} \mathrm{C}$ with $3 \%$ glutaraldehyde solution. The cells were rinsed thrice with PBS for 15 min each, after which they were incubated at $4^{\circ} \mathrm{C}$ for $1 \mathrm{~h}$ with $1 \%$ osmium tetroxide, followed by two $15-\mathrm{min}$ PBS washes. Next, the cells were incubated in 30, 50 and $70 \%$ 
ethanol at $4^{\circ} \mathrm{C}$ for $10 \mathrm{~min}$ each; in 80 and $90 \%$ ethanol at room temperature for $10 \mathrm{~min}$ each and in anhydrous ethanol (twice) at room temperature for $15 \mathrm{~min}$. The cells were then observed using a transmission electron microscope (H-7650; Hitachi High-Technologies Corporation).

Detection of cell morphology. The A549 cells were collected at the exponential growth stage and seeded into 24-well plates at a density of $5 \times 10^{4}$ cells/well. After culturing for at $37^{\circ} \mathrm{C}$ for $24 \mathrm{~h}$, the A549 cells were treated with 0,25 and $35 \mu \mathrm{mol} / 117 \mathrm{BIPHE} 2$ for $24 \mathrm{~h}$ at $37^{\circ} \mathrm{C}$ in a $5 \% \mathrm{CO}_{2}$ incubator. The medium was discarded and the cells were rinsed thrice with PBS, followed by the addition of $1 \mathrm{ml}$ freshly prepared $4 \%$ paraformaldehyde into each well and incubated for $1 \mathrm{~h}$ at room temperature. The cells were washed thrice with PBS, blocked in $3 \% \mathrm{H}_{2} \mathrm{O}_{2}$ at room temperature for $10 \mathrm{~min}$, washed again thrice with PBS, then incubated with $0.1 \%$ Triton-X 100-sodium citrate for $2 \mathrm{~min}$ for permeabilization. Next, the cells were washed thrice with PBS for 5 min each, followed by the addition of $50 \mu 1$ working TUNEL solution to each well and incubation for $1 \mathrm{~h}$ at $37^{\circ} \mathrm{C}$. Afterward, the cells were washed thrice with PBS and incubated with $50 \mu 1$ POD working solution for $30 \mathrm{~min}$ at $37^{\circ} \mathrm{C}$. The cells were again washed thrice with PBS for $5 \mathrm{~min}$ each, and incubated with the 3,3'-diaminobenzidine (DAB) substrates at room temperature for $10 \mathrm{~min}$. Morphological changes of A549 cells were observed under a microscope (Nikon Corporation) and 10 fields were observed under the microscope and the mean TUNEL positive ratio was counted.

Transwell assay to detect the effect of 17BIPHE2 on the migration and invasion of A549 cells. For the cell migration assay, the A549 cells were cultured to the exponential grow th stage and treated with 0,25 and $35 \mu \mathrm{mol} / 1$ 17BIPHE2 for $24 \mathrm{~h}$. The cells were digested with $0.25 \%$ trypsin without EDTA and washed twice with fresh PBS for $5 \mathrm{~min}$ each, after which they were resuspended in FBS-free RPMI-1640 medium. In the control group, $100 \mu 1$ of cells $\left(5 \times 10^{3}\right.$ cells/well $)$ were seeded in the upper chamber of the Transwell apparatus chamber in which the concentration of 17BIPHE2 was $0 \mu \mathrm{mol} / 1$. In the treatment group, the A549 cells were treated with 25 and $35 \mu \mathrm{mol} / 1$ 17BIPHE2 for $24 \mathrm{~h}, 100 \mu \mathrm{l}$ of these treated cells $\left(5 \times 10^{3}\right.$ cells/well) were added to the upper chamber. Then, $600 \mu$ l RPMI-1640 medium supplemented with $10 \%$ FBS was added to the lower chamber. After culturing for $24 \mathrm{~h}$ at $37^{\circ} \mathrm{C}$, the culture medium in the upper chamber was discarded, and the cells were fixed at room temperature for $30 \mathrm{~min}$ with $4 \%$ paraformaldehyde, and then stained with $0.5 \%$ purple crystal violet for $10 \mathrm{~min}$ at room temperature. Next, the cells were removed from the bottom of the upper chamber with a cotton swab and the number of cells that penetrated the membrane was counted using a light microscope. Each experiment was performed in duplicate and repeated thrice.

The procedure of the cell invasion assay was identical to that described above, except for the addition of $1 \mathrm{mg} / \mathrm{ml}$ Matrigel matrix (precoating for $30 \mathrm{~min}$ at $37^{\circ} \mathrm{C}$; Corning, Inc.) and culturing for $24 \mathrm{~h}$ at $37^{\circ} \mathrm{C}$. In brief, the six wells were coated with colloidal Matrigel and each well was filled with $3 \times 10^{4}$ A549 cells $/ \mathrm{ml}$ treated with 0,25 and $35 \mu \mathrm{mol} / 1$
17BIPHE2, then incubated at $37^{\circ} \mathrm{C}$ for $24 \mathrm{~h}$ before the number of invading cells was counted using a light microscope.

Detection of $24 \mathrm{~h}$ cell apoptosis rate using flow cytometry. Apoptosis assays were performed using the Annexin V apoptosis detection kit (Nanjing Fengfeng Biomedical Technology Co., Ltd.) according to the manufacturer's instructions. A549 cells in the exponential growth phase were resuspended in RPMI-1640 culture medium to a density of $1 \times 10^{8}$ cells $/ 1$. The cells were seeded and cultured in a six-well plate for $24 \mathrm{~h}$ and then treated with 0,25 and $35 \mu \mathrm{mol} / 1$ 17BIPHE2 for $24 \mathrm{~h}$. The culture solution was discarded, and the cells were washed twice with PBS and detached using trypsin and $0.25 \%$ EDTA (Beijing Solarbio Science \& Technology) in PBS for collection. After the 2-min reaction, excess trypsin was discarded and the digestion was continued for $3 \mathrm{~min}$ in trypsin. Afterwards, culture medium containing 10\% FBS was added. Finally, the cells were collected in a $1.5 \mathrm{ml}$ EP tube, followed by the addition of $400 \mu \mathrm{l}$ Annexin $\mathrm{V}$ binding solution and adjustment of the suspension concentration to $\sim 1 \times 10^{6}$ cells $/ \mathrm{ml}$. Then, $5 \mu$ l Annexin V-FITC working solution was added, and the cells were incubated in the dark for $15 \mathrm{~min}$ at $4^{\circ} \mathrm{C}$. Subsequently, $10 \mu \mathrm{l}$ PI working solution was added and the cells were incubated for $5 \mathrm{~min}$ in the dark at $4^{\circ} \mathrm{C}$. The samples were excited at $488 \mathrm{~nm}$ and detected using flow cytometry and FlowJo X 10.0.7 was used to analyze the data.

Microplate-based $\mathrm{Ca}^{2+}$ measurements. The A549 cells were detached at the exponential growth stage using trypsin with $0.25 \%$ EDTA in PBS and resuspended $\left(1 \times 10^{8}\right.$ cells/well) in FBS-free RPMI-1640 medium. The cells were then seeded in six-well plates and incubated at $37^{\circ} \mathrm{C}$ for $24 \mathrm{~h}$. The next day, the A549 cells were treated with 0,25 and $35 \mu \mathrm{mol} / 1$ 17BIPHE2 for 10,20 and $30 \mathrm{~min}$, respectively, and digested with $0.25 \%$ trypsin without EDTA. The A549 cells in the treatment and control groups were collected and cell suspensions of $\sim 1 \times 10^{6}$ cells $/ \mathrm{ml}$ were prepared after washing the cells thrice with PBS for 5 min each. Then, the calcium fluorescent probe Fluo-4AM working buffer was added (Beyotime Institute of Biotechnology) and the suspensions were incubated for $30 \mathrm{~min}$, followed by washing thrice with PBS for 5 min each. Finally, the cells were resuspended in cell culture medium without FBS and analyzed using flow cytometry as previously mentioned.

Analysis of the mitochondrial membrane potential $(\psi m)$. A549 cells in the logarithmic growth phase were treated with $0.25 \%$ trypsin with EDTA and harvested, followed by resuspension in RPMI-1640 medium supplemented with $10 \%$ FBS to a concentration of $1 \times 10^{8}$ cells/l. The cells were plated in six-well plates with $5 \times 10^{3}$ cells per well and incubated for $24 \mathrm{~h}$ at $37^{\circ} \mathrm{C}$. The next day, the A549 cells were treated with 0,25 and $35 \mu \mathrm{mol} / 1$ 17BIPHE2 for $24 \mathrm{~h}$ at $37^{\circ} \mathrm{C}$, followed by treatment with $0.25 \%$ trypsin without EDTA. The collected A549 cells were washed twice for 5 min each with 0.1 M PBS, and incubated with the JC-1 working buffer (Beijing Solarbio Science \& Technology) for $20 \mathrm{~min}$ at $37^{\circ} \mathrm{C}$. Then, cell culture medium without FBS was added to the six-well plates, and emission fluorescence was detected at $525 \mathrm{~nm}$ using flow cytometry as previously mentioned. 
Determination of intracellular reactive oxygen species (ROS) levels. A549 cells in the exponential growth stage were detached using trypsin with $0.25 \%$ EDTA in PBS, plated in six-well plates with $5 \times 10^{3}$ cells per well, and treated with 0,25 and $35 \mu \mathrm{mol} / 1$ 17BIPHE2 for $30 \mathrm{~min}$ at $37^{\circ} \mathrm{C}$. Intracellular ROS production was detected using the ROS assay kit (Beyotime Institute of Biotechnology) according to the manufacturer's instruction. The A549 cells were collected, washed thrice with PBS for 5 min each, and incubated with DCFH-DA working solution, which was diluted 1:1,000-fold with serum-free medium to a final concentration of $10 \mu \mathrm{mol} / \mathrm{l}$. The cells were collected and suspended in diluted DCFH-DA at the concentration of 1-20 million cells $/ \mathrm{ml}$, and incubated at $37^{\circ} \mathrm{C}$ for $20 \mathrm{~min}$. The samples were mixed by inversion every 3-5 $\mathrm{min}$. The cells were washed thrice with serum-free cell culture medium to remove the DCFH-DA at did not enter the cells. Then, the cells were gently mixed and placed in a cell culture incubator. After $30 \mathrm{~min}$ at $37^{\circ} \mathrm{C}$, the cells were washed thrice with PBS for 5 min each, followed by the addition of the cell culture medium without FBS and the detection at $488 \mathrm{~nm}$ using flow cytometry as previously mentioned.

Protein extraction and western blotting. The A549 cells were seeded in T-75 flask plates and cultured for $24 \mathrm{~h}$ until the cells reached a confluence of $80-90 \%$. Next, 0,25 and $35 \mu \mathrm{mol} / 1$ 17BIPHE2 was added and the cells were incubated for $24 \mathrm{~h}$. The medium then was aspirated, and the cells were harvested and washed twice with pre-cold PBS buffer with shaking several times to remove the culture solution. Then, the cells were centrifuged at $800 \times \mathrm{g}$ at $37^{\circ} \mathrm{C}$ for $30 \mathrm{sec}$ and lysed via violent oscillations for $30 \mathrm{sec}$ in pre-cooled lysis buffer containing $1 \mathrm{x}$ protease and phosphatase inhibitors. The samples placed on ice and removed every $4 \mathrm{~min}$, which was repeated five times. Next, the cells were centrifuged at $16,000 \mathrm{x} \mathrm{g}$ at $4^{\circ} \mathrm{C}$ for $30 \mathrm{~min}$ and the supernatant was collected. Protein concentration was determined using a bicinchoninic acid protein assay kit (Nanjing KeyGen Biotech Co., Ltd.). The proteins were denatured at $95^{\circ} \mathrm{C}$ for $10 \mathrm{~min}$ and $30-50 \mu \mathrm{g}$ of each protein was loaded per lane and separated on a $10-15 \%$ sodium dodecyl sulfate-polyacrylamide gel. Next, the proteins were electro-transferred to a polyvinylidene fluoride membrane. The membrane was blocked with $5 \%$ skimmed milk or bovine serum albumin (5\% BSA for the phosphorylated protein; Beijing Solarbio Science \& Technology Co., Ltd.) at room temperature for $1 \mathrm{~h}$, followed by overnight incubation at $4^{\circ} \mathrm{C}$ with the following antibodies: Anti-ERK (1:5,000; Abcam), anti-p-ERK (1:5,000; Abcam), anti-BCL-2 (1:1,000; Abcam) and anti-BAX (1:1,000; Abcam). The next day, the blots were washed thrice with Tris-buffered 5\% saline-Tween-20 (TBST) for $5 \mathrm{~min}$ each, followed by incubation with the secondary antibody HRP-conjugated Affinipure Goat Anti-rabbit IgG $(\mathrm{H}+\mathrm{L})(1: 10,000$ in TBST and 5\% skim milk; Abcam) at room temperature for $1 \mathrm{~h}$. The blots were then again washed thrice with TBST for $5 \mathrm{~min}$ each. The enhanced chemiluminescence substrate (Thermo Fisher Scientific, Inc.) was used to detect the protein bands and images were captured using the Chemidoc XRS system (Bio-Rad Laboratories, Inc.). GAPDH and $\beta$-actin (both 1:1,000; Abcam) were used as internal controls as the molecular weight of ERK is close to that of GAPDH, while the molecular weight of $\beta$-actin is larger compared with of ERK.
Relative protein levels were determined using the ImageJ 1.8.0 software (National Institutes of Health).

RNA interference. A549 cells $\left(5 \times 10^{5}\right.$ cells/1) in the logarithmic growth phase were seeded in six-well plates and cultured with 2 ml RPMI1640 with 10\% FBS per well for $24 \mathrm{~h}$ until confluence of $60-70 \%$ was reached at the time of transfection. The sequences were as follows: siRNA-ERK, 5'-GAGCAA AUGAAAGAUGUAUTT-3' and siRNA-Control, 5'-UUC UCCGAACGUGUCACGUTT-3'. In total, 80 pmol siRNA (siRNA-ERK or siRNA Control, Shanghai GenePharma Co., Ltd.) or $3.75 \mu 1$ Lipofectamine ${ }^{\circledR} 3000$ (Invitrogen; Thermo Fisher Scientific, Inc.) reagent was diluted in $125 \mu 1$ opti-MEM (Gibco; Thermo Fisher Scientific, Inc.) and incubated at room temperature for $5 \mathrm{~min}$. The diluted siRNA was added to each tube of diluted Lipofectamine 3000 reagent (1:1 ratio) and incubated for $15 \mathrm{~min}$ at room temperature to form the siRNA-lipid complex. Then, the siRNA-lipid complex was added to the A549 cells and incubated for $24 \mathrm{~h}$. The transfection efficiency was visualized using western blot analysis. si-RNA-transfected A549 cells were treated with 17BIPHE2 (25 or $35 \mu \mathrm{mol} / \mathrm{l}$ ) and apoptosis was detected using flow cytometry. Western blotting was used to detect the expression of ERK, p-ERK, BAX and BCL-2 in A549 cells as aforementioned.

In vivo xenotransplanted tumor model. In total, SPF grade BALB/C nude mice ( $\mathrm{n}=24$, average body weight of $18-22 \mathrm{~g}$ ) were obtained from Beijing Medical University Animal Research Center and raised in the Experimental Animal Center of the Ningxia Medical University. The study was approved by the Animal Experimentation Committee of The Ningixia Medical University (Yin Chuan, China). Animals were clinically healthy and kept under hygienic conditions in plastic cages in an environment maintained at $24 \pm 2^{\circ} \mathrm{C}, 55 \pm 10 \%$ humidity and $12 / 12 \mathrm{~h}$ cycle of light and darkness for acclimatization. The animals had free access to standard pellet diet and water ad libitum. A549 cells $\left(5 \times 10^{6}\right.$ cells/mouse) were injected subcutaneously near the axilla into the right flank of BALB/c nude mice $(n=5$ per experimental group) to form xenograft tumors and tumor formation and volume were monitored on alternate days. After 21 days, tumors with diameters of $\sim 5 \mathrm{~mm}$ were observed in the back, indicating that the nude mouse model of lung adenocarcinoma was successfully established. Nude mice were divided into four groups: Negative control (PBS injection), low-dose 17BIPHE2 treatment $(10 \mathrm{mg} / \mathrm{kg})$, high-dose 17BIPHE2 treatment $(20 \mathrm{mg} / \mathrm{kg}$ ) and positive control (paclitaxel injection, $10 \mathrm{mg} / \mathrm{kg}$ ). The body weight and tumor growth of the nude mice were observed for two week after the peptide treatment. Tumor length and width were measured every other day from the day of A549 cell injection, and the tumor volume was calculated as follows: Tumor volume $(\mathrm{V})=\left(\right.$ length $\mathrm{x}$ width $\left.{ }^{2} / 2\right)$. At 4 weeks post-cell injection, the mice were sacrificed and the tumors were removed and measured. The mice were placed in a $10-\mathrm{L}$ box, and $\mathrm{CO}_{2}$ was slowly filled at a flow rate of $20 \%$ to make the indoor air and $\mathrm{CO}_{2}$ reach equilibrium. The mice were observed continuously until they did not move (rigor mortis).

Detection of the morphology of transplanted tumor cells using the TUNEL assay. Tissue samples from the negative control 
(PBS), low-dose treatment (25 $\mu \mathrm{mol} / 1$ 17BIPHE2) and high-dose treatment group (35 $\mu \mathrm{mol} / 1$ 17BIPHE2) were sectioned using a freezing microtome, fixed with $4 \%$ paraformaldehyde and washed thrice with PBS for 30 min each. Then, the samples were blocked with sealing buffer $\left(3 \% \mathrm{H}_{2} \mathrm{O}_{2}\right.$ in methanol) at room temperature for $10 \mathrm{~min}$, and washed thrice with PBS for 5 min each, followed by treatment with permeabilizing buffer (Triton X-100 in $0.1 \%$ sodium citrate) at room temperature for 2 min. After washing thrice with PBS, the TUNEL working buffer was added, and the samples were placed in a cell culture box for $1 \mathrm{~h}$. After washing thrice with PBS for 5 min each, the samples were incubated with POD working buffer for 30 min, followed by three washes with PBS and incubation with DAB at room temperature for $10 \mathrm{~min}$. After two PBS washes, the samples were covered with neutral balsam and images were captured using a light microscope for five fields of each group.

Immunohistochemistry (IHC) for Ki67. IHC was performed according to the manufacturer's instructions of KI67 Cell Proliferation kit (Sangon Biotech Co., Ltd.) to detect Ki67 expression in the transplanted tumor. Briefly, fresh tumor tissue samples from the negative control (PBS), low-dose treatment (25 $\mu \mathrm{mol} / \mathrm{l}$ 17BIPHE2) and high-dose treatment groups (35 $\mu \mathrm{mol} / 1$ 17BIPHE2) were fixed by soaking in $10 \%$ formalin and were embedded in paraffin overnight at $65^{\circ} \mathrm{C}$. Then, the samples were sectioned at $4-\mu \mathrm{m}$ thickness after heating for $10 \mathrm{~min}$ at $37^{\circ} \mathrm{C}$, deparaffinized in xylene, and rehydrated in graded ethanol [100 (twice), 90, 80, 70, 50 and $0 \%$, each for $5 \mathrm{~min})$. The tissue sections were immersed into a dye vat filled with the antigen repair solution and incubated under high pressure for $5 \mathrm{~min}$ in a pressure cooker to remove the endogenous peroxidase. After removing the water from the tissue sections, the samples were incubated with $3 \% \mathrm{H}_{2} \mathrm{O}_{2}$ in a wet box for $15 \mathrm{~min}$ at room temperature and washed thrice with PBS for 5 min each to remove the excess $\mathrm{H}_{2} \mathrm{O}_{2}$. The slides were then incubated with goat serum (Gibco; Thermo Fisher Scientific, Inc.) for $20 \mathrm{~min}$ at room temperature. Subsequently, the slides were incubated overnight with mouse anti-Ki67 (cat. no. PB9026; 1:200; Wuhan Boster Biological Technology, Ltd.) antibody at $4^{\circ} \mathrm{C}$. The next day, the samples were removed and equilibrated at room temperature for $30 \mathrm{~min}$. The primary antibody was washed off with PBS. Next, the slides were incubated with reagent $\mathrm{A}$ at $37^{\circ} \mathrm{C}$ for $20 \mathrm{~min}$, washed thrice with PBS for 5 min each, and incubated with reagent $\mathrm{B}$ at $37^{\circ} \mathrm{C}$ for $30 \mathrm{~min}$. The slides were washed thrice with PBS for 5 min each and then incubated with DAB (1:20) for 2-10 min for color development, and the reaction was stopped using pure water. Then the nuclei were re-stained for 4 min with hematoxylin at room temperature, rinsed thoroughly with pure water and dipped in tap water until the color returned to blue. All slides were dehydrated with graded ethanol $[50,70,80,90$, 100 (twice) and 50\% each for $2 \mathrm{~min}]$ and covered with neutral balsam for analysis under light microscope with five fields of each group.

Statistical analysis. All values were expressed as mean \pm standard deviation calculated from three independent experiments. The data were analyzed with one-way ANOVA followed by Tukey's multiple comparison post hoc tests
(SPSS 17.0; SPSS, Inc.). P $<0.05$ was considered to indicate a statistically significant difference.

\section{Results}

Effects of the antibacterial peptide 17BIPHE2 on the proliferation of lung cancer cells. To confirm the cytotoxic effect of 17BIPHE2 in a concentration $(0,5,10,15,20,25,30$, 35 and $40 \mu \mathrm{mol} / \mathrm{l}$ ) -and time ( 24 and $48 \mathrm{~h}$ )-dependent manner, the viability of treated A549 and NCI-H1975 cells and that of the normal human lung epithelial cell line BEAS-2B was evaluated using the MTT assay. After treatment with various concentrations of 17BIPHE2 $(0-40 \mu \mathrm{mol} / \mathrm{l})$ for $24 \mathrm{~h}$, the viability of the A549 cells decreased from $99.1 \pm 1.3$ to $40.3 \pm 0.7 \%$, with a determined $\mathrm{IC}_{50}$ value of $34.33 \mu \mathrm{mol}$ (Fig. 1A). The viability of the NCI-H1975 cells treated with 0-40 $\mu \mathrm{mol} / 1$ 17BIPHE2 from $99.2 \pm 2.0 \%(0 \mu \mathrm{mol} / 1)$ to $71.6 \pm 2.9 \%$, respectively, and the $\mathrm{IC}_{50}$ was $71.42 \mu \mathrm{mol} / 1$. 17BIPHE2 treatment showed an inhibitory effect on the viability of A549 and NCI-H1975 cells from $5 \mu \mathrm{mol} / 1$, while treatment with RI-10 at the same concentration range $(0-40 \mu \mathrm{mol} / \mathrm{l})$ for $24 \mathrm{~h}$ did not show any significant inhibitory effect (Fig. 1B). The proliferation of BEAS-2B cells was inhibited neither by 17BIPHE2 nor by RI-10 (Fig. 1C). Overall, the results showed that 17BIPHE2 inhibited the proliferation of A549 and NCI-H1975, and the $\mathrm{IC}_{50}$ of NCI-H1975 was higher compared with that of A549.

17BIPHE2 induced cell-cycle arrest in the $G_{I} / S$ phase. Next, it was investigated whether the proapoptotic effect of 17BIPHE2 is indeed mediated by the inhibition of cell proliferation. To this end, the effect of 17BIPHE2 on the cell cycle in A549 cells was analyzed using flow cytometry. As shown in Fig. 2, significant $S$ phase arrest was observed in A549 cells was detected after treatment with 25 and $35 \mu \mathrm{mol} / 1$ 17BIPHE2 for $24 \mathrm{~h}$. This effect was dose- and time-dependent. In contrast to this, the number of cells in the $\mathrm{G}_{0} / \mathrm{G}_{1}$ phase decreased with increasing 17BIPHE2 concentrations. The number of cells in the $\mathrm{G}_{2} / \mathrm{M}$ phase increased in response to $35 \mu \mathrm{mol} / 1$ 17BIPHE2 compared with $0 \mu \mathrm{mol} / 1$ group. These results indicated the mechanism of 17BIPHE2 action involves the inhibition of the proliferation of A549 cells and cell cycle arrest at the S phase.

17BIPHE2 inhibits the migration and invasion of lung cancer cells in vitro. To further investigate the effect of 17BIPHE2 in vitro, cell migration and invasion assays were performed with A549 cells treated with 25 and $35 \mu \mathrm{mol} / \mathrm{l}$ 17BIPHE2 for $24 \mathrm{~h}$. The results showed that compared with $0 \mu \mathrm{mol} / 1$ control group, the migration rates of the A549 cells treated with 25 and $35 \mu \mathrm{mol} / 1$ 17BIPHE2 were $65.6 \pm 6.3$ and $23.7 \pm 1.3 \%$, respectively. The corresponding invasion rates at the above indicated 17BIPHE2 concentrations were $34.2 \pm 1.2$ and $9.2 \pm 0.9 \%$, respectively. Thus, both migration and invasion of the lung cancer cells showed a downward trend after 17BIPHE2 treatment (Fig. 3). Overall, the results revealed that 17BIPHE2 attenuated cell migration and invasion in a dose-dependent manner.

17BIPHE2-treated A549 cells show typical morphological characteristics of apoptotic cells. To investigate the morphological changes in apoptotic cells, A549 cells were 

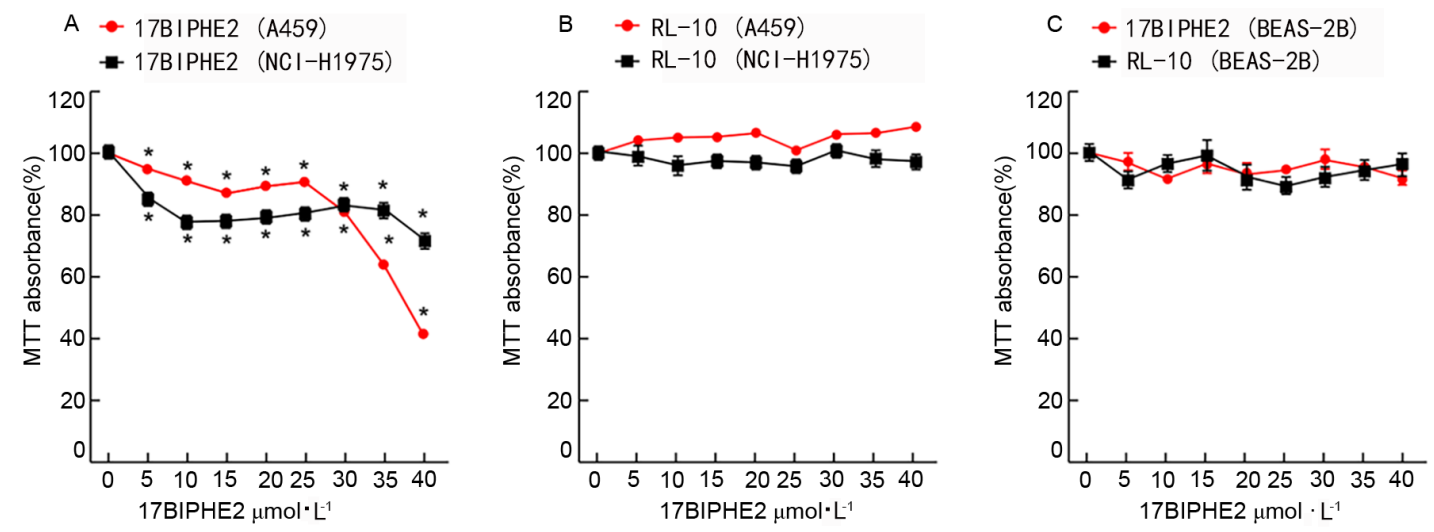

Figure 1. Cytotoxic effect of 17BIPHE2 and RL-10 on human lung adenocarcinoma A549, NCI-H1975 and normal lung epithelial BEAS-2B cells. (A) Treatment of A549 and NCI-H1975 cells with various concentrations of 17BIPHE2 (0-40 $\mu \mathrm{mol} / \mathrm{l})$ for $24 \mathrm{~h}$. (B) A549 and NCI-H1975 cells were treated with 0-40 $\mu$ mol/1 RL-10. (C) BEAS-2B cells were treated with 17BIPHE2 and RI-10. "P<0.05 compared with $0 \mu \mathrm{mol} / 1$ 17BIPHE2 control.
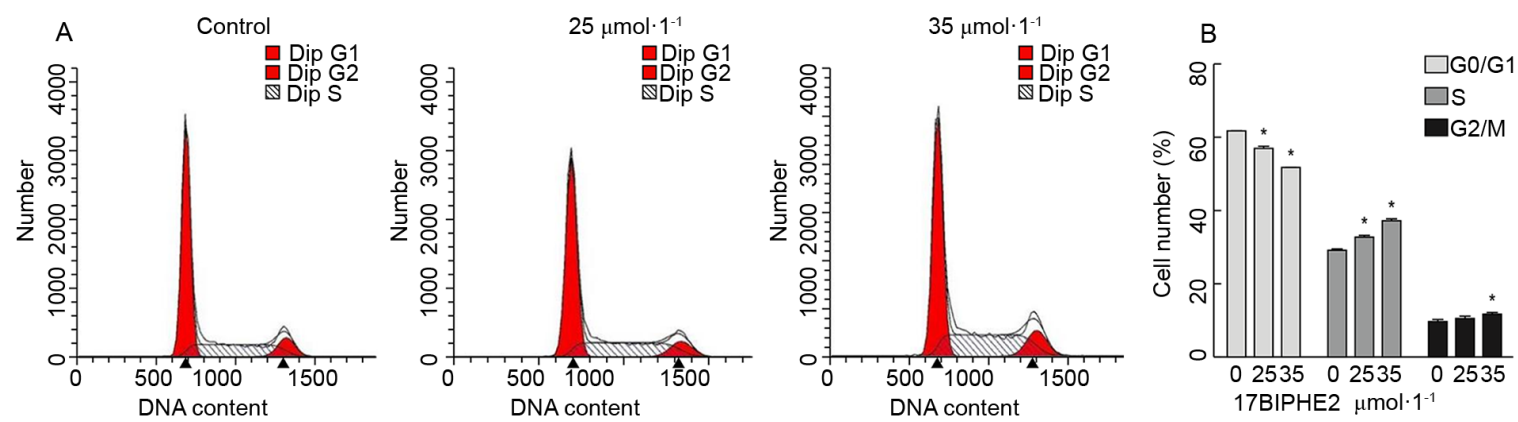

Figure 2. (A) Effects of 17BIPHE2 on cell cycle progression in human lung carcinoma A549 cells. (B) The number of cells in the G2/M phase increased in response to $35 \mu \mathrm{mol} / 1$ 17BIPHE2 compared with $0 \mu \mathrm{mol} / 1$ group."P $<0.05$ compared with the control group.
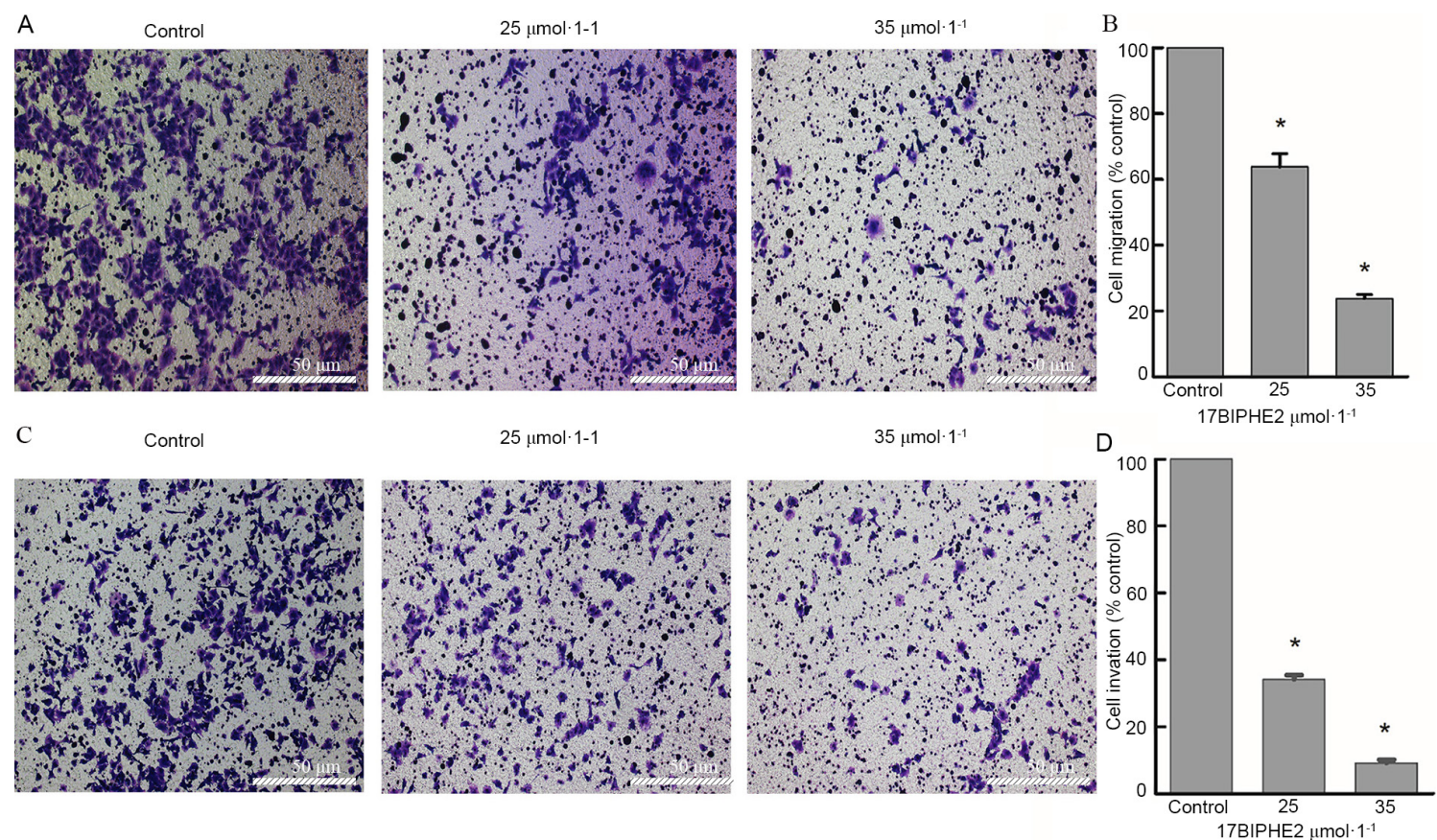

Figure 3. Effects of 17BIPHE2 on the migration and invasion of human lung carcinoma A549 cells after treatment with BIPHE2. (A and B) Images of Transwell assays of A549 cells. (C and D) Quantification of the number of (B) migratory and (D) invasive cells. Scale bar, $50 \mathrm{~nm}$. ${ }^{*} \mathrm{P}<0.05$ compared with the control group.

treated with 25 and $35 \mu \mathrm{mol} / 1$ 17BIPHE2 for $24 \mathrm{~h}$. Cell morphology was analyzed using transmission electron microscopy. Cells in the control group had visible organelles in the cytoplasm with complete structure, large number 


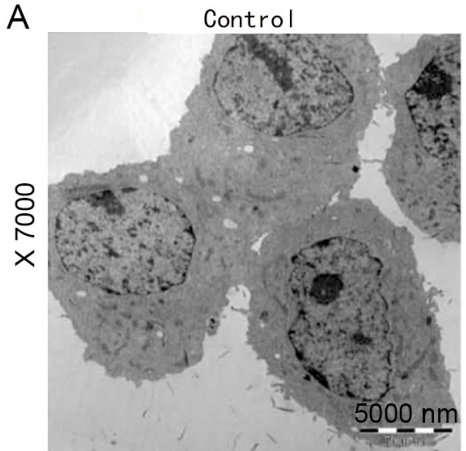

B

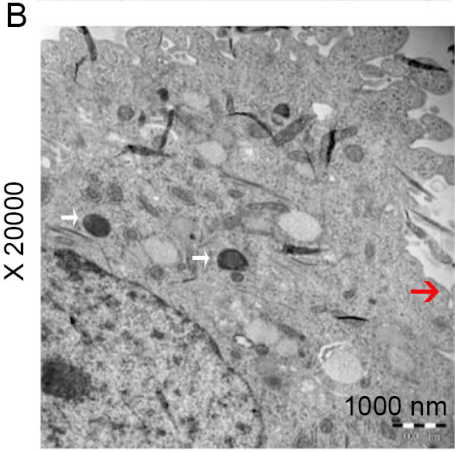

$25 \mu \mathrm{mol} \cdot \mathrm{L}^{-1}$
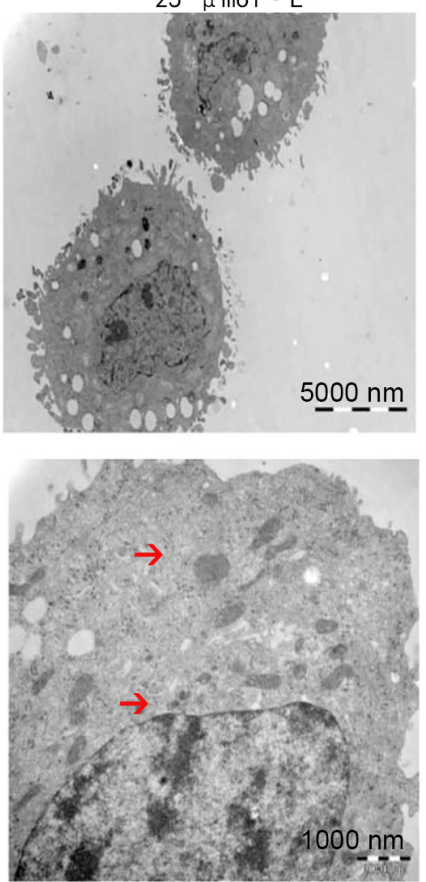

$35 \mu \mathrm{mol} \cdot \mathrm{L}^{-1}$
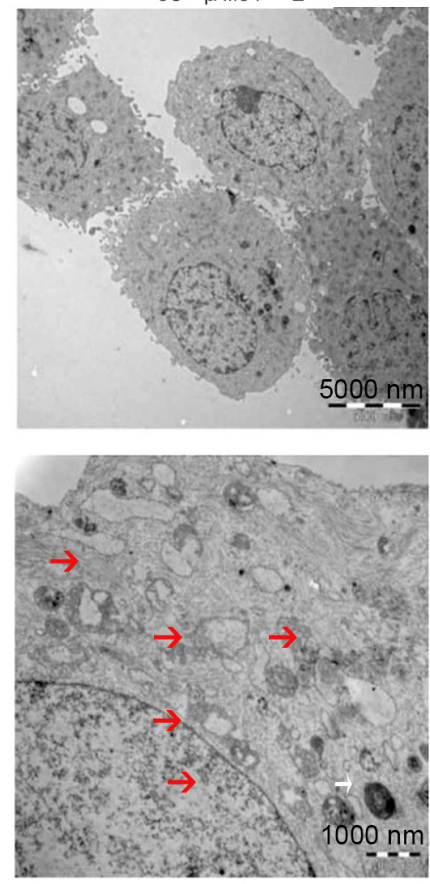

Figure 4. Electron microscopy images of A549 cells treated with 25 and $35 \mu \mathrm{mol} / 1$ 17BIPHE2 at (A) x700 and (B) x2,000 magnification.

of endoplasmic reticula, ribosome, mitochondria, uniform distribution of chromatin in the nucleus and a clear nucleoli structure. In contrast to this, treatment with $25 \mu \mathrm{mol} / 1$ 17BIPHE2 increased the number of intracytoplasmic vacuoles and induced nuclear wrinkling, apoptotic body formation and cytoskeleton disintegration. The peptide also damaged the mitochondrial crest. Furthermore, cells treated with $35 \mu \mathrm{M}$ 17BIPHE2 showed destruction of the cytoplasmic organelle structure, mitochondrial ridge rupture, endoplasmic reticulum swelling and vacuolation (Fig. 4).

17BIPHE2 induces apoptosis in A549 cells. The morphological changes in A549 cells were evident after 17BIPHE2 treatment, especially after treatment with high concentrations of the peptide. Cell shrinkage was induced after treatment with $25 \mu \mathrm{mol} / 1$ 17BIPHE2 for $24 \mathrm{~h}$ (Fig. 4), which may have contributed to apoptosis. It was confirmed that 17BIPHE2 promoted apoptosis using Annexin V/PI staining coupled with flow cytometry. As shown in Fig. 5A, the early apoptotic fraction increased when cells were treated with $25 \mu \mathrm{mol} / 1$ 17BIPHE2, while treatment with $35 \mu \mathrm{mol} / 1$ 17BIPHE2 increased both the early and late apoptotic fractions, compared with the control cells. These observations indicated that the proportion of apoptotic cells increased in a concentration-dependent manner after 17BIPHE2 treatment (Fig. 5A). Furthermore, the apoptosis rate of the A549 cells increased significantly with 17BIPHE2 concentration ( $\mathrm{P}<0.05$; Fig. 5B).

To further demonstrate the ability of 17BIPHE2 to induce apoptosis in lung cancer cells, a TUNEL assay was performed using A549 cells treated with 25 and $35 \mu \mathrm{mol} / 1$ 17BIPHE2 for $24 \mathrm{~h}$. In the control group, the nuclei were round and uniformly brown and lightly stained, and the chromatin distribution was uniform. In contrast to this, after treatment 17BIPHE2, the cells showed typical apoptotic morphological characteristics such as cell shrinkage, dense and hyperchromatic chromatin and loss of integrity (Fig. 5B). Furthermore, the apoptosis rate of A549 cells increased significantly with 17BIPHE2 concentration $(\mathrm{P}<0.05$; Fig. $5 \mathrm{~B})$.

17BIPHE2 induces apoptosis in lung cancer cells via the mitochondria-mediated apoptotic pathway. Apoptosis is mediated by two major pathways, namely the death-receptor pathway and the mitochondrial pathway (12). Therefore, the loss of $\psi \mathrm{m}$, which is another hallmark of apoptosis (13) was further determined. Accordingly, A549 cells were treated with 25 and $35 \mu \mathrm{mol} / 1$ 17BIPHE2 for $24 \mathrm{~h}$, followed by measurement of $\psi \mathrm{m}$. The results showed that $\psi \mathrm{m}$ decreased significantly as the concentration of 17BIPHE2 increased ( $<<0.05$; Fig. 6). Taken together, these results demonstrated that 17BIPHE2 can induces apoptosis in A549 cells via mitochondrial dysfunction in a dose-dependent manner.

Intracellular $\mathrm{Ca}^{2+}$ and ROS levels are elevated in A549 cells after 17BIPHE2 treatment. To further examine whether 17BIPHE2-induced apoptosis is ROS-mediated and/or associated with the intracellular calcium ion concentration, the intracellular calcium and ROS levels in A549 cells after treatment with 25 and $35 \mu \mathrm{mol} / 1$ 17BIPHE2 for 10, 20 and 30 min was determined. The results showed that the $\mathrm{Ca}^{2+}$ level in A549 cells increased significantly $(\mathrm{P}<0.05)$ with the concentration of 17BIPHE2. This indicated that 17BIPHE2 increases intracellular $\mathrm{Ca}^{2+}$ activity significantly in a timeand dose-dependent manner (Fig. 7A and B). In addition, 17BIPHE2 induced apoptosis in lung cancer cells also in a ROS-dependent manner (Fig. 7C and D), because flow cytometry analysis showed that the intracellular ROS levels in A549 cells were significantly elevated in a 17BIPHE2 concentration-dependent manner. 
A

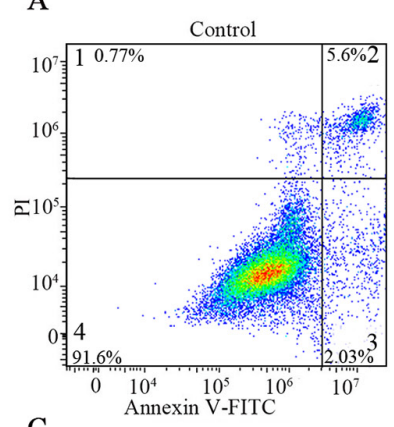

c
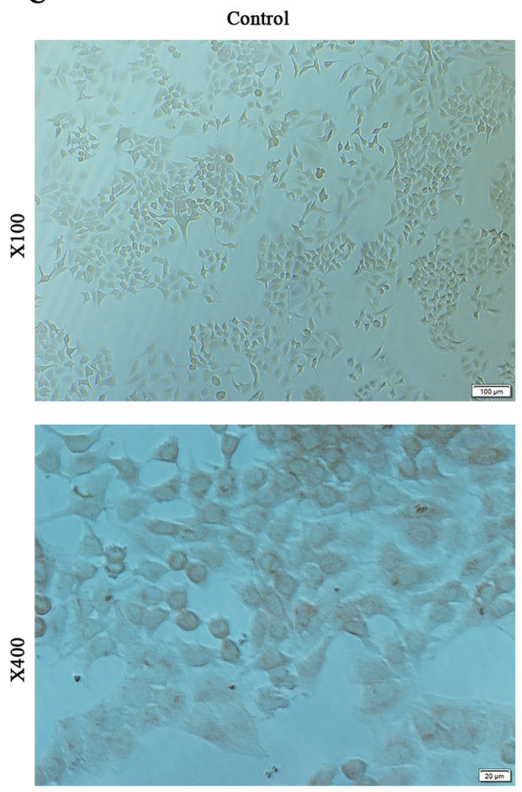
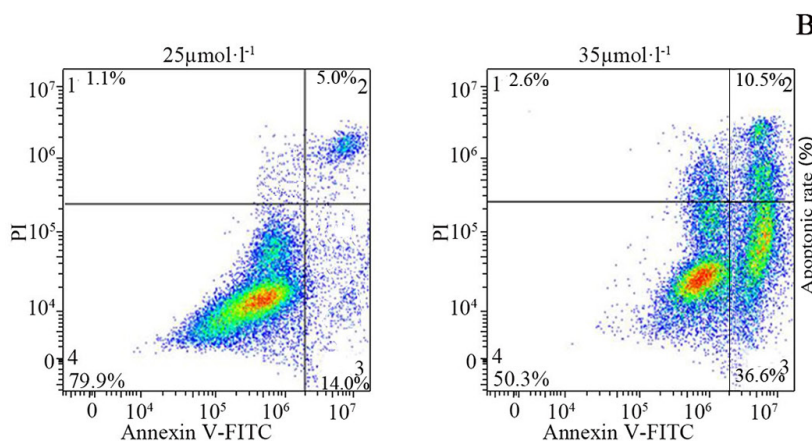

B

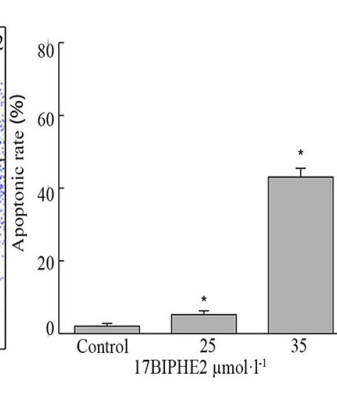

$35 \mu \mathrm{mol} \cdot \mathrm{r}^{-1}$
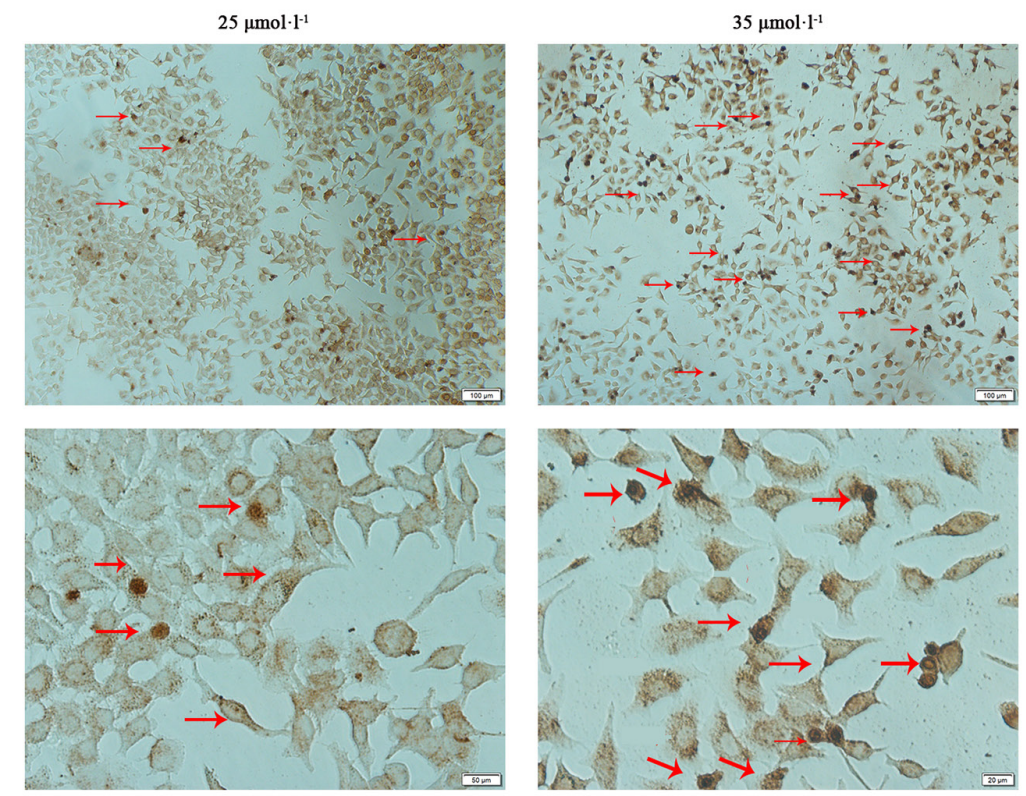

Figure 5. 17BIPHE2 induces apoptosis in A549 cells. Apoptosis detection was performed with flow cytometry using PI and Annexin V-FITC double staining. (A) Apoptosis rate in A549 cells detected using flow cytometry. (B) Quantified flow cytometry results. (C) Morphological characteristics of apoptotic A549 cells assessed using TUNEL staining. ${ }^{*} \mathrm{P}<0.05$ compared with the control.

A

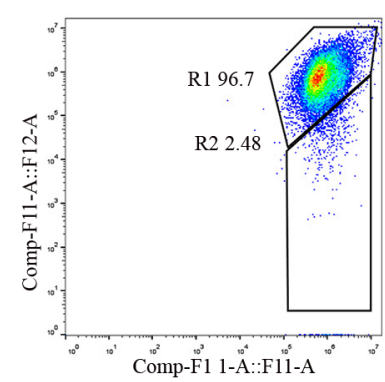

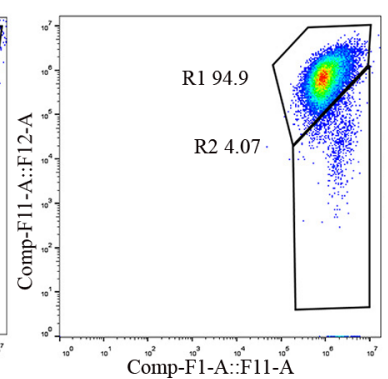
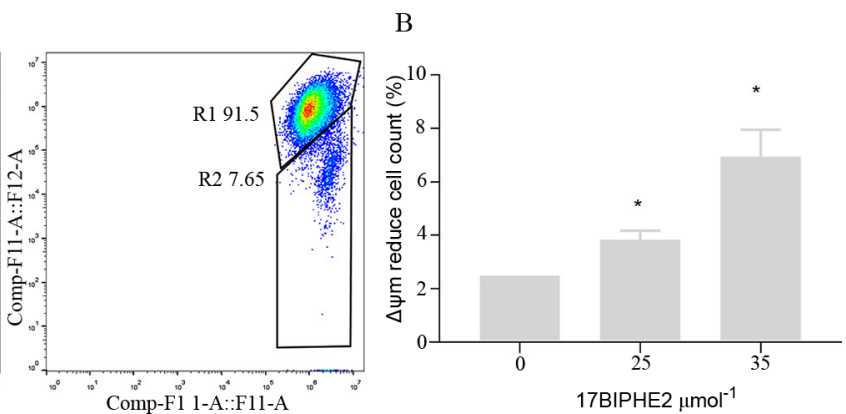

Figure 6. 17BIPHE2 induces apoptosis associated with the loss of mitochondrial membrane potential in A549 cells. (A) A549 cells were treated with 25 and $35 \mu \mathrm{mol} / 1$ 17BIPHE2 for $24 \mathrm{~h}$. (B) The $\psi \mathrm{m}$ decreased significantly as the concentration of 17BIPHE2 increased. RI control apoptosis rate, R2 control reduced cells count (\%). ${ }^{*} \mathrm{P}<0.05$ compared with $0 \mu \mathrm{mol} / 1$ 17BIPHE2 control.

17BIPHE2 elevatesp-ERKandBAXlevelswhile downregulating the expression of ERK and BCL-2. Next, the effect of a 24-h treatment with 25 and $35 \mu \mathrm{mol} / 1$ 17BIPHE2 on the endogenous expression of ERK, p-ERK, BAX and BCL-2 was investigated in A549 cells using western blot analysis (Fig. 8A and C). The protein levels of p-ERK and BAX were upregulated in 17BIPHE2-treated cells compared with those in the control group. In contrast to this, the expression of ERK and BCL-2 was significantly downregulated in the peptide-treated A549 cells compared with that in the untreated cells. Importantly, the p-ERK/ERK ratio increased significantly after treatment with the peptide. To further evaluate the effect of 17BIPHE2 on the expression of ERK, p-ERK, BAX and BCL-2 in A549 cells, ERK expression was silenced using siRNA targeting ERK and it 

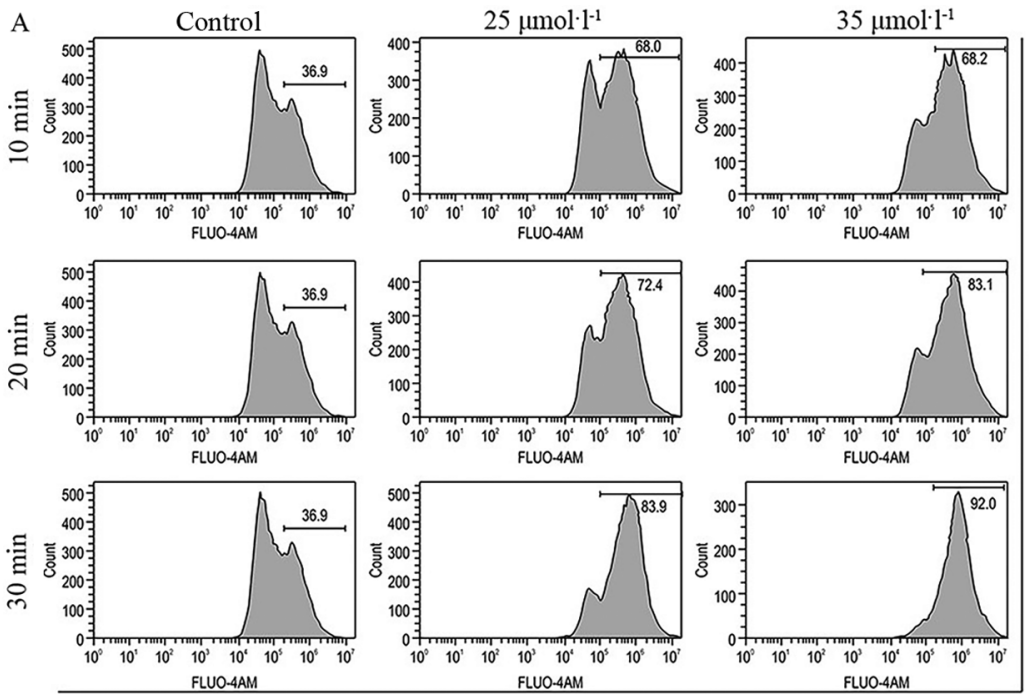

FLUO-4AM

$\mathrm{C}$

Control

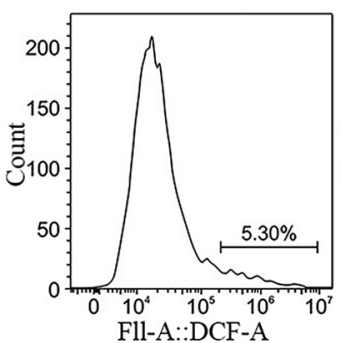

$25 \mu \mathrm{mol} \cdot \mathrm{l}^{-1}$

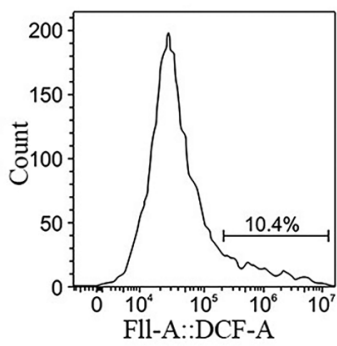

$35 \mu \mathrm{mol} \cdot \mathrm{l}^{-1}$

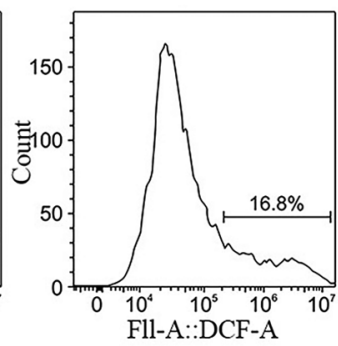

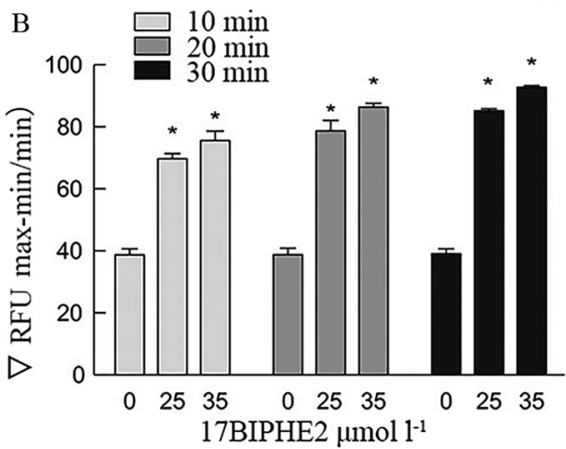

$\mathrm{D}$

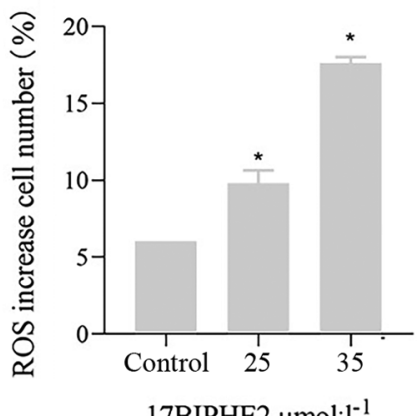

17BIPHE2 $\mu \mathrm{mol} \cdot \mathrm{l}^{-1}$

Figure 7. Intracellular ROS levels are elevated in A549 cells after 17BIPHE2 treatment. (A and B) 17BIPHE2 induced dose-dependent apoptosis in human lung cancer stained with Annexin V-FITC/propidium iodide. (C and D) 17BIPHE2 induced ROS accumulation in A549 cells. "P<0.05 compared with 10 min or control.

was observed that knockdown significantly affected the protein levels of lung cancer cells compared with that of cells transfected with the negative control siRNA $(\mathrm{P}<0.05$; Fig. $8 \mathrm{G}$ and $\mathrm{H})$. Flow cytometry analysis showed that the apoptotic ratio in A549 cancer cells significantly increased when they were transfected with siRNA targeting ERK after treatment with 0 and $35 \mu \mathrm{mol} / \mathrm{l}$ 17BIPHE2 for $24 \mathrm{~h}$ (Fig. 8B). However, the apoptotic rate in A549 cells in the control group was significantly lower compared with that in the si-ERK-treated group $(\mathrm{P}<0.05$; Fig. 8D). These data showed that 17BIPHE2-induced apoptosis of A549 cells was regulated by ERK. Next, the role of ERK in 17BIPHE2-induced apoptosis was assessed in A549 cells using western blot analysis. The results showed, that after si-ERK transfection, cells treated with 17BIPHE2 showed significantly lower expression levels of ERK and p-ERK compared with the NC-transfected cells (Fig. 8E and F). Furthermore, BAX was significantly upregulated in the si-ERK group treated with $25 \mu \mathrm{mol} / 1$ 17BIPHE2 compared with the control group; however, it was upregulated when the cells were treated with $35 \mu \mathrm{mol} / 1$ 17BIPHE2 $(\mathrm{P}<0.05)$. The ratio of BAX/BCL-2 in the si-ERK group was upregulated, indicating that $\mathrm{p}-\mathrm{ERK}$ regulates the levels of BAX and BCL-2 in A549 cells, which in turn regulates 17BIPHE2-induced apoptosis in A549 cells (Fig. 8G and H).

17BIPHE2 decreases the tumorigenicity of lung cancer cells in vivo. The effect of 17BIPHE2 in vivo was validated in the
BALB/c mouse model of lung tumor. Mouse xenograft models were established by subcutaneously injecting A549 cells $\left(5 \times 10^{6}\right.$ cells/mouse) into the right flank of BALB/c nude mice, and tumor formation and volume were monitored on alternate days. The tumor grew rapidly and locally after the injection, and after 21 days, the tumor size was $\sim 5 \mathrm{~mm}$ in diameter, indicating that the mouse xenograft model was successfully established. Tumor sizes of the tumors in four groups was measured after two weeks of treatment with 17BIPHE2. The body weights differed between the negative control group $(22.06 \pm 1.46 \mathrm{~g})$, low-dose treatment $(21.20 \pm 1.41 \mathrm{~g})$, high-dose treatment $(21.42 \pm 0.94 \mathrm{~g})$ and positive control groups $(20.93 \pm 1.03 \mathrm{~g})$. The mice were sacrificed and the tumors were dissected and images were captured. The tumor sizes in the low-dose and high-dose treatment groups were significantly lower compared with those in the negative control group $(\mathrm{P}<0.05$; Fig. 9A and B). Thus, 17BIPHE2 significantly reduced tumor volume in xenograft mice and thereby decreased the tumorigenicity of lung cancer cells in vivo.

17BIPHE2 suppresses lung tumor growth and inhibits proliferation in vivo. To further determine the effects of 17BIPHE2 on apoptosis and proliferation in A549 cells in vivo, TUNEL staining of tumor samples from nude mice treated with 17BIPHE2 was performed. TUNEL staining of 17BIPHE2 treated tumor sections showed that the cell nuclei 

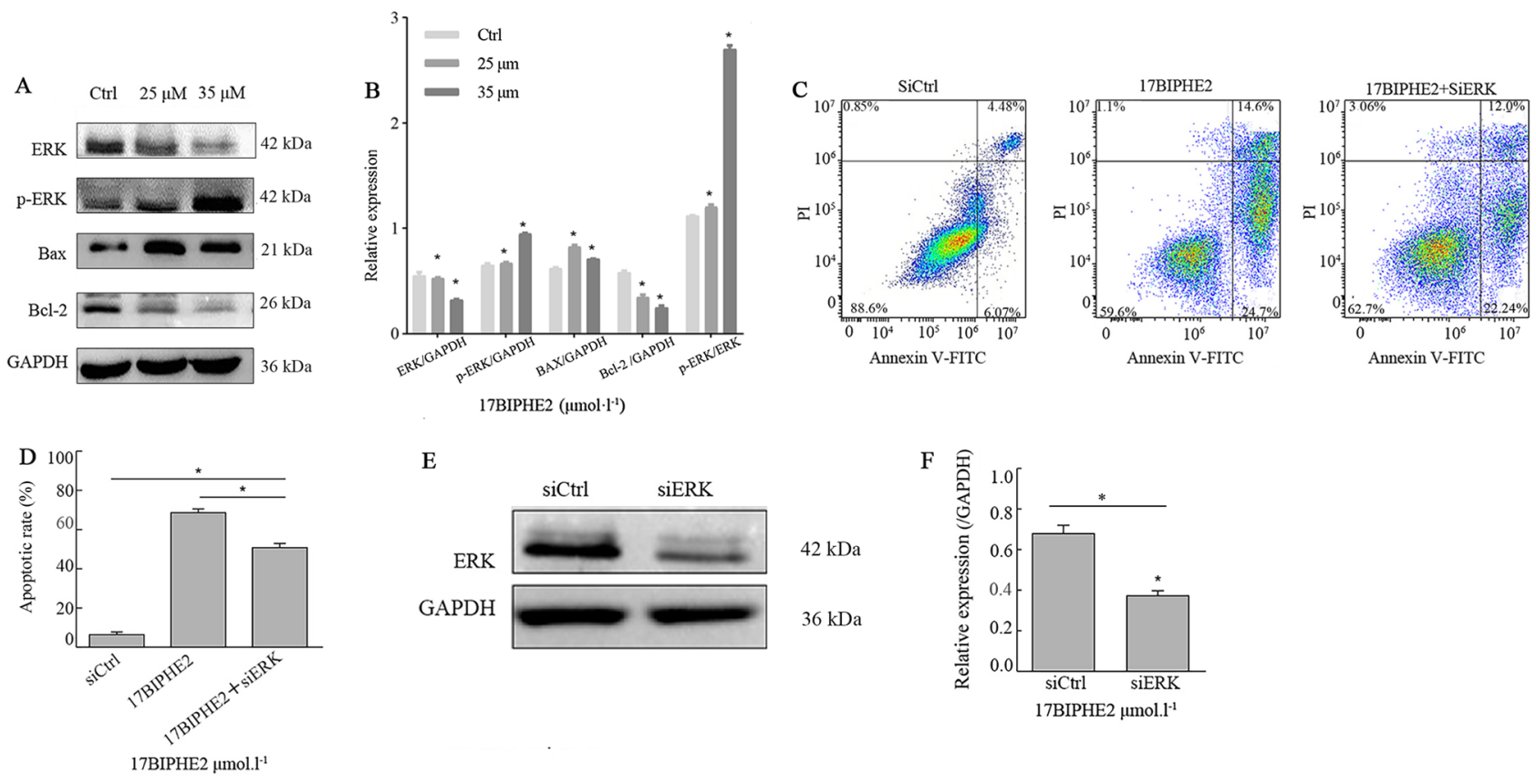

$\mathrm{E}$
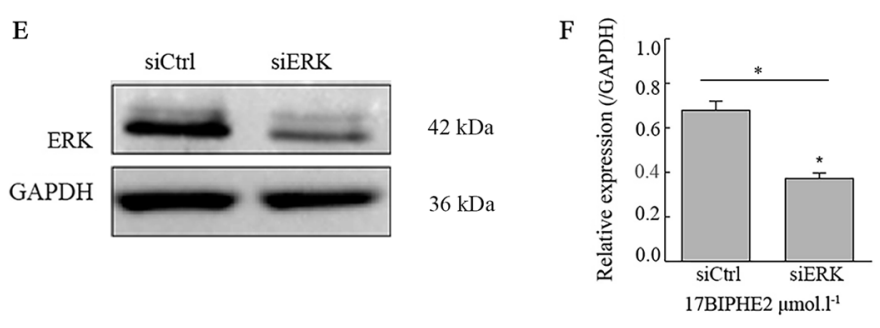

G
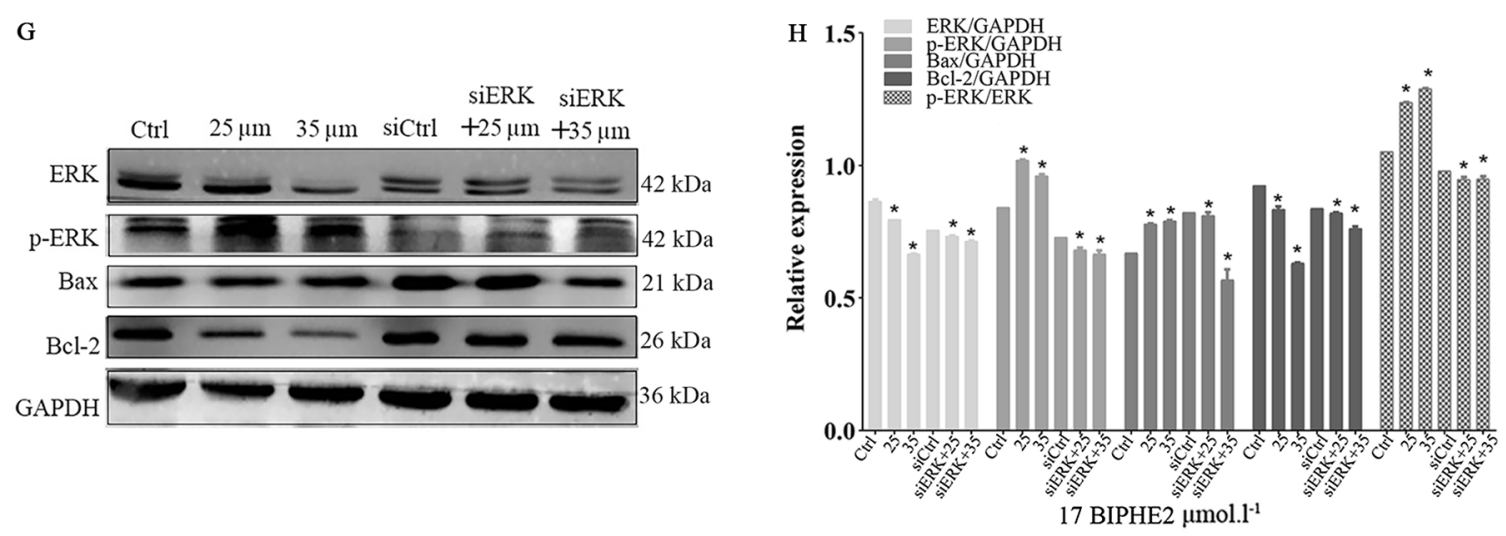

Figure 8. 17BIPHE2 elevates p-ERK and BAX levels while downregulating the expression of ERK and BCL-2. (A and B) Expression of ERK, p-ERK, Bax and Bcl-2 was analyzed using western blotting. (C and D) Apoptosis rate was measured using flow cytometry. (E and F) siRNA treatment in A549 cells. $(\mathrm{G}$ and $\mathrm{H})$ ERK, p-ERK, Bax, BCL-2 expression. " $\mathrm{P}<0.05$ and compared with the respect $\mathrm{Ctrl}$. p-, phosphorylated; si, small interfering; Ctrl, control.

stained brown and yellow (Fig. 10A). Most of the transplanted tumor cells in the PBS-treated group were cancer cells, and hardly any apoptotic cells were observed. Compared with the PBS group, the groups treated with 10 and $20 \mathrm{mg} / \mathrm{kg}$ 17BIPHE2 had an increased number of apoptotic cells in the transplanted tumor (Fig. 10B). It was then examined whether this finding was associated with the proliferation of A549 cells. For this reason, tumor samples were sectioned and analyzed using immunohistochemistry for Ki67 expression, which is highly expressed in proliferating cells (13). Compared with the cells in the control (PBS) group, 17BIPHE2-treated cells showed suppressed expression of Ki67, shown by the tan, diffuse and granular staining of Ki67 (Fig. 10B). Taken together, these data demonstrated that 17BIPHE2 attenuated tumor growth via induction of apoptosis in tumor cells and inhibition of proliferation ability of the transplanted tumors.

\section{Discussion}

17BIPHE2 is a derivative of LL-37 and has lower hemolytic activity and cytotoxicity compared with LL-37 (5). 17BIPHE2 have hardly been addressed in research to the best of our knowledge, especially its effects on lung cancer. Research shows that LL-37 plays an important role in antibacterial (14) and antitumor responses (15). The results showed that 17BIPHE2 promoted apoptosis in lung cancer A549 cells. In addition, 17BIPHE2 inhibited tumor growth in vivo and cell proliferation in vitro. Therefore, the present study sought to investigate whether 17BIPHE2 has similar functions to LL-37 and aimed to explore the effects of 17BIPHE2 on lung cancer.

LL-37 is a C-terminal cleavage product of hCAP-18, which is mainly expressed within neutrophils $(3,4,9,16-19)$. A study reported that LL-37 has multiple biological functions, including antibacterial, antiviral, antifungal and antiparasitic effects, at low concentrations (20). In addition, LL-37 inhibits the formation of bacterial biofilms (21). The peptide does not only directly eliminate harmful pathogenic microorganisms, but it also regulates immune responses, which requires the interaction between multiple molecules and cells involved in the innate and adaptive immunity (22). However, research shows that LL-37 may participate in the pathogenesis of malignant tumors by regulating apoptosis in colorectal 
A
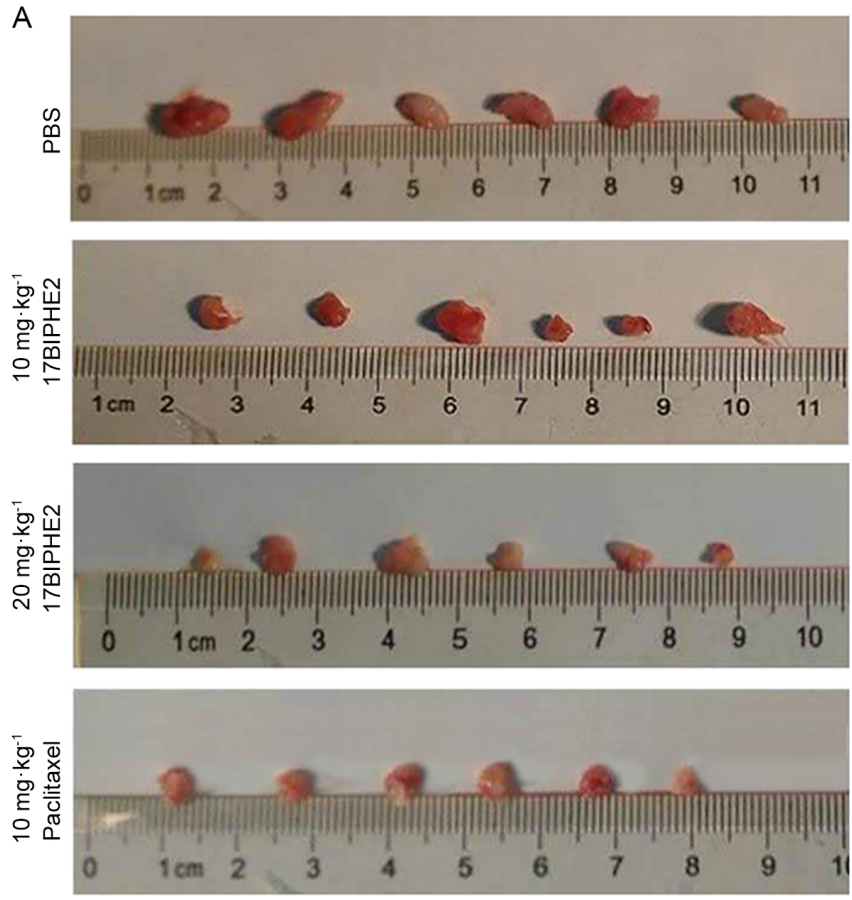

B

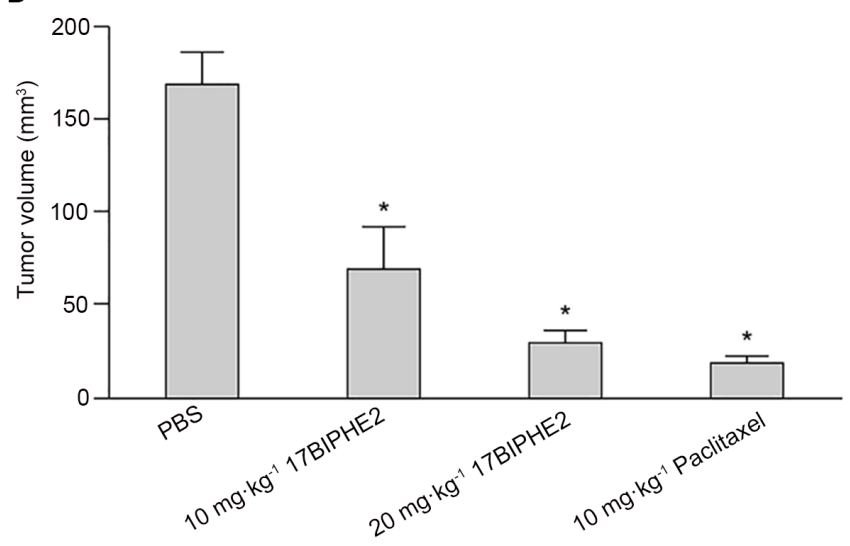

Figure 9. 17BIPHE2 reduces lung adenocarcinoma tumor growth in a xenograft mouse model. (A) Tumor images. (B) Quantified tumor volume data. ${ }^{*} \mathrm{P}<0.05$ compared with the PBS group. PBS, phosphate buffered saline.

cancer (23), bladder cancer (24) and leukemia (8). LL-37 exerts its antitumor effects by inducing apoptosis in cancer cells (25). However, LL-37 has been shown to promote the growth of and has variable expression in ovarian cancer (26), malignant melanoma (27) and lung cancer (28). The role of LL-37 is also tissue-specific (29). Studies have indicated that LL-37 plays a prominent and complex role in antitumor response (26). Overexpression of LL-37 promotes the development and progression of ovarian, lung and breast cancer, and it suppresses tumorigenesis in colon and gastric cancer (30). Under normal conditions, LL-37 plays a role in the tumor surveillance system. However, since LL-37 is involved in proliferation, migration and angiogenesis, uncontrolled expression of LL-37 could also lead to aberrant control of the aforementioned processes and promote cancer development (31).

LL-37 kills tumor cells by regulating the cytotoxicity of natural killer cells (32-34). Previously, numerous studies have reported that LL-37 inhibits the proliferation of various tumor cell lines such as those from colorectal cancer (25), leukemia (34) and bladder cancer (35). In the present study, it was demonstrated that the antimicrobial peptide 17BIPHE2 affected the proliferation, migration and invasion of human lung adenocarcinoma A549 cells. 17BIPHE2 exerted cytotoxic effects on A549 cells but not in normal pulmonary epithelial BEAS-2B and NCI-H1795 cells. The MTT assay showed an evident dose- and time-dependent antiproliferative effect for 17BIPHE2 in A549 cells. Meanwhile, 17BIPHE2 did not inhibit the proliferation of BEAS-2B cells, indicating that the peptide was selective lung adenocarcinoma cells, and hence has potential as an adjuvant drug for the treatment of lung cancer.

NSCLC (of which A549 cell is the most typical cell line) accounts for the largest proportion of lung cancer cases (36). The poor prognosis in lung cancer is associated with tumor metastasis (37). Cancer metastasis includes uncontrolled cell proliferation, angiogenesis, adhesion, migration and invasion (34). Metastasis is one of causes of treatment failure in some malignant tumors (38). A number of studies have confirmed that antimicrobial peptides can inhibit tumor cell proliferation (39-41). Liu et al (42) showed that the antimicrobial peptide Cecropin XJ effectively inhibits the migration and invasion of human gastric cancer AGS cells. Tian et al (43) reported that the migratory ability and invasiveness of breast cancer cells were inhibited by the antimicrobial peptide RP39. The present study showed that the cell migration and invasion of A549 cells were inhibited by 17BIPHE2 in a dose-dependent manner when the cells were treated with 25 and $35 \mu \mathrm{mol} / 1$ 17BIPHE2 for $24 \mathrm{~h}$.

Inhibition of cell proliferation is closely associated with cell cycle regulation as an anticancer mechanism, and apoptosis usually follows cell cycle arrest (44). The cell cycle represents a survival mechanism for tumor and normal cells because it allows cells to repair damaged DNA (45). In the present study, the cell cycle of A549 cells was arrested at the $S$ phase by 17BIPHE2 treatment, which would have inhibited DNA synthesis $(46,47)$ and damage repair and thereby prevented cells from entering the division phase. These results demonstrating DNA damage in S phase are consistent with those of Guangrui et al (24). A previous study showed that bladder cancer EJ and T24 cells were arrested at the S phase by the antimicrobial peptide LL-37 (48). The mechanism of action includes either the direct binding of antibacterial peptides to the DNA or the inhibition of DNA polymerase activity. However, most studies have reported that tumor cell cycle arrest induced by antimicrobial peptides occurs at the $\mathrm{G}_{1} / \mathrm{S}$ phase (49). Although 17BIPHE2 blocked the tumor cell cycle of A549 cells at the $\mathrm{S}$ phase in the present study, the peptide showed a strong inhibitory effect on the proliferation of tumor cells. Overall, it was demonstrated that 17BIPHE2 can promote apoptosis and inhibit cell proliferation by blocking the cell cycle of A549 cells.

Morphological changes accompany apoptosis and the main characteristics of apoptotic cells include nuclear shrinkage, DNA fragmentation, chromatin condensation, mitochondrial crest rupture, loss of cell adhesion, cell fragmentation into apoptotic bodies, and vacuolation and destruction of the endoplasmic reticulum (50). In the current study, 17BIPHE2-treated A549 cells exhibited morphological characteristics of apoptosis. TUNEL staining and transmission 
A

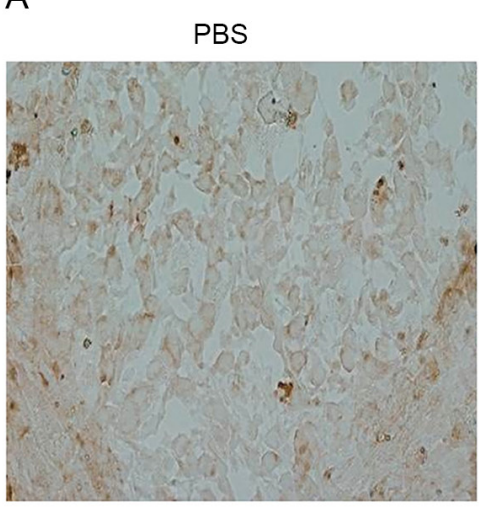

B

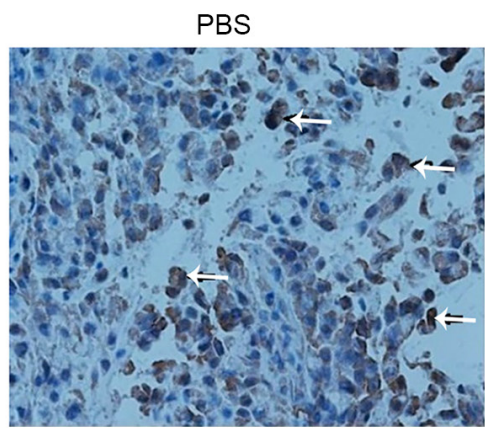

$10 \mathrm{mg} \cdot \mathrm{kg}^{-1}$

17BIPHE2

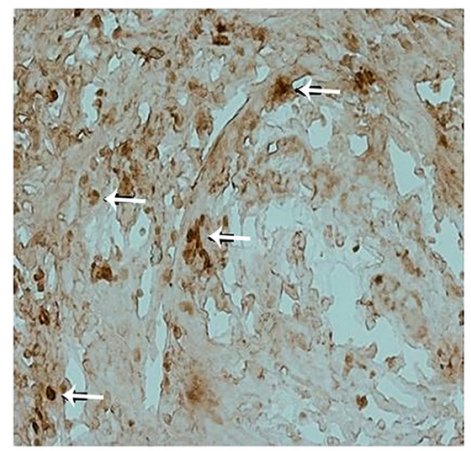

$10 \mathrm{mg} \cdot \mathrm{kg}^{-1}$

17BIPHE2

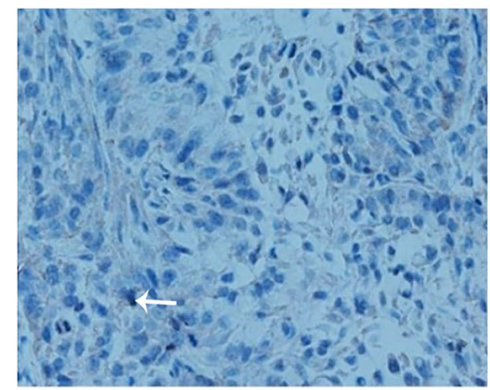

$20 \mathrm{mg} \cdot \mathrm{kg}^{-1}$

17BIPHE2
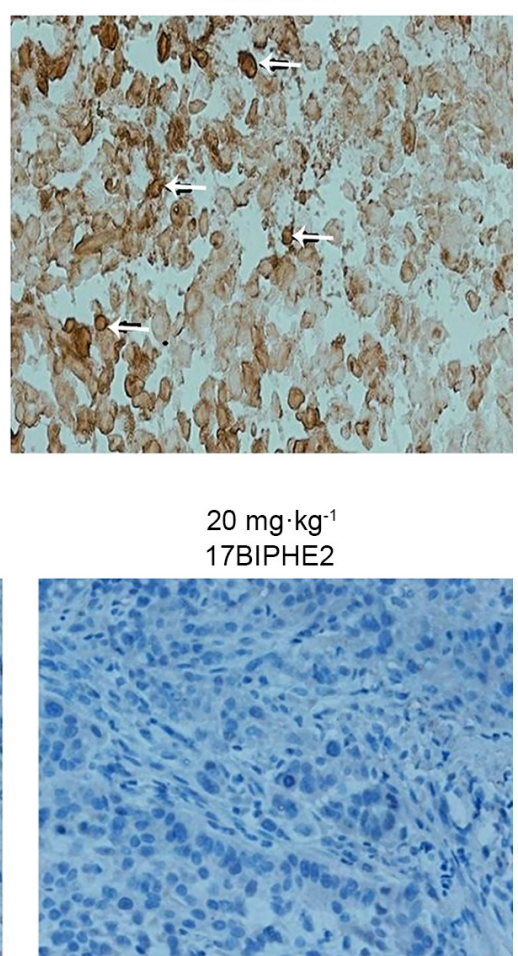

Figure 10. 17BIPHE2 suppresses lung tumor growth and inhibits proliferation in vivo. (A) TUNEL apoptosis of tumor cells. (B) Expression of Ki67 in tumor cells. PBS, phosphate buffered saline.

electron microscopy showed that 17BIPHE2 treatment of A549 cells led to nuclear shrinkage, chromatin condensation and darkening, mitochondrial ridge rupture, vacuolization of the endoplasmic reticulum and the destruction of its normal structure (51). Compared with the control group, treatment with $25 \mu \mathrm{mol} / 1$ 17BIPHE2 significantly increased the percentage of early apoptotic cells, while treatment with $35 \mu \mathrm{mol} / 1$ 17BIPHE2 increased the percentage of cells in both the early and late apoptotic stages. These results demonstrated that 17BIPHE2 induced apoptosis by inhibiting the proliferation of lung cancer cells.

The results of the present animal experiment showed that 17BIPHE2 promoted apoptosis of tumor cells also in vivo. TUNEL staining of tumor sections from xenograft mice with transplanted tumors showed that the number of apoptotic cells in the 17BIPHE2 treatment group was higher compared with that in the negative control group. The results of immunohistochemical staining showed that Ki67 expression was significantly lower in the 17BIPHE2 treatment group compared with in the negative control group, indicating that the proliferative activity of the transplanted tumor in the treatment group was reduced.

In summary, the antimicrobial peptide 17BIPHE2 exhibited anti-lung cancer effects in vitro and in vivo by blocking the cell cycle, inhibiting migration and invasion and promoting apoptosis of A549 cells. Extensive research has revealed the pivotal role of mitochondria in apoptosis. Mitochondria are the executors of apoptosis (52). A previous study revealed that the change in the mitochondrial $\Delta \psi \mathrm{m}$ is the earliest change observed in cells after the after initiation of apoptosis (53). Mitochondria store calcium and thus regulate the intracellular levels of calcium. When the level of accumulated $\mathrm{Ca}^{2+}$ in the mitochondria exceeds the threshold of the highly conductive permeability transition pore, the pore opens, leading to a reduction in the mitochondrial membrane potential, enhanced permeability and apoptosis (54). ROS are the products of cellular metabolism, which are continuously produced and cleared in cells and play important roles in the occurrence of apoptosis (55). ROS accumulation and the increase in $\mathrm{Ca}^{2+}$ concentration coincide. Oxidative pressure increases the $\mathrm{Ca}^{2+}$ levels in the cytoplasm and eventually leads to calcium overload in the mitochondria. This further increases intracellular ROS levels, which in turn stimulates the release of intracellular calcium reserves and results in the intracellular accumulation of $\mathrm{Ca}^{2+}$ (56). In the present study, $\psi \mathrm{m}$ decreased significantly when A549 cells were treated with 17BIPHE2. However, intracellular $\mathrm{Ca}^{2+}$ and ROS levels increased significantly and were associated with increasing concentrations of 17BIPHE2.

ERK is a serine/threonine protein kinase, which is ubiquitous in eukaryotic cells and is a member of the MAPK family of proteins (57). Kuriyama et al (58) observed that ROS and $\mathrm{Ca}^{2+}$ activate the ERK signaling pathway and participate in the regulation of cell proliferation, differentiation, and apoptosis. Chuang et al (53) also reported that ROS activates ERK to mediate apoptosis in skin cells. Cabrera Zapata et al (59) revealed that neuronal cell apoptosis is regulated by ERK, which is activated by $\mathrm{Ca}^{2+}$. BCL-2 has an important function in the apoptosis process (60). Liu et al (61) found that the downregulation of BCL-2 expression can promote apoptosis in 
Vero cells. Under normal circumstances, BAX mainly exists in the cytoplasm. When cells are stimulated by apoptotic signals, BAX is transferred from the cytoplasm to the mitochondria, where it increases mitochondrial permeability and mediates apoptosis (62). Wang et al (63) observed that p-ERK can regulate the ratio of $\mathrm{BAX} / \mathrm{BCL}-2$ to regulate apoptosis of pancreatic tumor cells. In addition, Wang et al (64) revealed that increased expression of p-ERK and BCL-2 and decreased expression of $\mathrm{BAX}$ reduces the apoptotic rate in mouse nerve cells, thereby protecting them from apoptotic cell death. In the present study, the expression of p-ERK and BAX was higher in A549 cells treated with 17BIPHE2 compared with in untreated control cells. BCL-2 was downregulated, and the BAX/BCL-2 ratio was increased after 17BIPHE2 treatment. After si-ERK transfection, the expression of ERK, p-ERK and BAX decreased, whereas that of BCL-2 increased compared with the corresponding expression rates in the control group. The BAX/BCL-2 ratio also decreased significantly with treatment with the peptide. These results indicated that $\mathrm{p}-\mathrm{ERK}$ regulates BAX and BCL-2 in A549 cells, which in turn regulates apoptosis mediated by the antimicrobial peptide 17BIPHE2.

The antibacterial peptide 17BIPHE2 inhibited the proliferation of lung adenocarcinoma A549 cells. Furthermore, it blocked the cell cycle at the $\mathrm{G}_{1} / \mathrm{S}$ phase, decreased the mitochondrial membrane potential and elevated the ROS and $\mathrm{Ca}^{2+}$ levels, thereby promoting apoptosis and inhibiting the proliferation of A549 cells. 17BIPHE2 treatment also activated ERK, which regulated the expression of the apoptosis-related proteins BAX and BCL-2 to mediate apoptosis of A549 cells further. However, the mechanism of action underpinning the anticancer action of 17BIPHE2 is still unclear, therefore further studies are required to lay a foundation for future clinical application.

\section{Acknowledgements}

The authors would like to thank Professor Guangshun Wang (Department of Pathology and Microbiology, College of Medicine, University of Nebraska Medical Center, Omaha, NE, USA) who designed and synthesized 17BIPHE2.

\section{Funding}

This research was supported by The National Natural Science Foundation of China (grant nos. 81560573 and 81760661).

\section{Availability of data and materials}

All data are available from the corresponding author upon reasonable request.

\section{Authors' contributions}

TY and JL confirm the authenticity of all raw data. JL conceived and designed the present study, acquired, analyzed and interpreted the data. TY drafted the manuscript and analyze the relevant data. QJ prepared some relevant experimental data. YW, QZ and SZ contributed to the data analysis of this paper. XW helped analyze the data and critically revised the manuscript for important intellectual content. All authors read and approved the final manuscript.

\section{Ethics approval and consent to participate}

The present study was approved by the Animal Experimentation Committee of The Ning Xia of Medical University (Yin Chuan, China).

\section{Patient consent for publication}

Not applicable.

\section{Competing interests}

The authors declare that they have no competing interests.

\section{References}

1. Singh RD, Shandilya R, Bhargava A, Kumar R, Tiwari R, Chaudhury K, Srivastava RK, Goryacheva IY and Mishra PK: Quantum dot based nano-biosensors for detection of circulating cell free miRNAs in lung carcinogenesis: From Biology to Clinical translation. Front Genet 9: 616, 2018

2. Chen W, Zheng R, Baade PD, Zhang S, Zeng H, Bray F, Jemal A, $\mathrm{Yu}$ XQ and He J: Cancer statistics in China, 2015. CA Cancer J Clin 66: 115-132, 2016.

3. Fahy RJ and Wewers MD: Pulmonary defense and the human cathelicidin hCAP-18/LL-37. Immunol Res 31: 75-89, 2005.

4. Gennaro R and Zanetti M: Structural features and biological activities of the cathelicidin-derived antimicrobial peptides. Biopolymers 55: 31-49, 2015.

5. Wang X, Mishra B, Lushnikova T, Narayana JL and Wang G: Amino acid composition determines peptide activity spectrum and hot-spot-based design of merecidin. Adv Biosyst 2: 1700259, 2018.

6. Wang G, Hanke ML, Mishra B, Lushnikova T, Heim CE, Chittezham Thomas V, Bayles KW and Kielian T: Transformation of human cathelicidin LL-37 into selective, stable, and potent antimicrobial compounds. ACS Chem Biol 9: 1997-2002, 2014.

7. Zasloff M: Antimicrobial peptides of multicellular organisms. Nature 415: 389-395, 2002.

8. Mader JS, Mookherjee N, Hancock RE and Bleackley RC: The human host defense peptide LL-37 induces apoptosis in a calpainand apoptosis-inducing factor-dependent manner involving Bax activity. Mol Cancer Res 7: 689-702, 2009.

9. Xu Z, Zhang F, Bai C, Yao C, Zhong H, Zou C and Chen X: Sophoridine induces apoptosis and $\mathrm{S}$ phase arrest via ROS-dependent JNK and ERK activation in human pancreatic cancer cells. J Exp Clin Cancer Res 36: 124, 2017.

10. McCubrey JA, Steelman LS, Chappell WH, Abrams SL, Wong EW, Chang F, Lehmann B, Terrian DM, Milella M, Tafuri A, et al: Roles of the Raf/MEK/ERK pathway in cell growth, malignant transformation and drug resistance. Biochim Biophys Acta 1773: 1263-1284, 2007.

11. Le Chevalier T: Adjuvant chemotherapy for resectable non-small-cell lung cancer: Where is it going?. Ann Oncol 21 (Suppl 7): vii196-vii198, 2010.

12. Hu L, Zhang T, Liu D, Guan G, Huang J, Proksch P, Chen X and Lin W: Notoamide-type alkaloid induced apoptosis and autophagy via a P38/JNK signaling pathway in hepatocellular carcinoma cells. RSC Adv 9: 19855-19868,2019.

13. Tian SW, Ren Y, Pei JZ, Ren BC and He Y: Pigment epithelium-derived factor protects retinal ganglion cells from hypoxia-induced apoptosis by preventing mitochondrial dysfunction. Int J Ophthalmol 10: 1046-1054, 2017.

14. Kang J, Dietz MJ and Li B: Antimicrobial peptide LL-37 is bactericidal against Staphylococcus aureus biofilms. PLoS One 14: e0216676, 2019.

15. Ko JK and Zhang Z: LL-37 inhibits pancreatic cancer development through inhibition of autophagy and reprogramming of the tumor microenvironment. Pergamon 110: S5-S6, 2019. 
16. Agerberth B, Charo J, Werr J, Olsson B, Idali F, Lindbom L, Kiessling R, Jörnvall $\mathrm{H}$, Wigzell $\mathrm{H}$ and Gudmundsson $\mathrm{GH}$ : The human antimicrobial and chemotactic peptides LL-37 and alpha-defensins are expressed by specific lymphocyte and monocyte populations. Blood 96: 3086-3093, 2000.

17. Dale BA and Fredericks LP: Antimicrobial peptides in the oral environment: Expression and function in health and disease. Curr Issues Mol Biol 7: 119-133, 2005.

18. Rico-Mata R, De Leon-Rodriguez LM and Avila EE: Effect of antimicrobial peptides derived from human cathelicidin LL-37 on Entamoeba histolytica trophozoites. Exp Parasitol 133 300-306, 2013

19. Rekha RS, Rao Muvva SS, Wan M, Raqib R, Bergman P, Brighenti S, Gudmundsson GH and Agerberth B: Phenylbutyrate induces LL-37-dependent autophagy and intracellular killing of Mycobacterium tuberculosis in human macrophages. Autophagy 11: 1688-1699, 2015.

20. Bucki R, Leszczýnska K, Namiot A and Sokołowski W: Cathelicidin LL-37: A multitask antimicrobial peptide. Arch Immunol Ther Exp (Warsz) 58: 15-25, 2010.

21. Dosler S and Karaaslan E: Inhibition and destruction of Pseudomonas aeruginosa biofilms by antibiotics and antimicrobial peptides. Peptides 62: 32-37, 2014.

22. Amatngalim GD, Nijnik A, Hiemstra PS and Hancock RE: Cathelicidin Peptide LL-37 Modulates TREM-1 expression and inflammatory responses to microbial compounds. Inflammation 34: 412-425, 2011

23. Shaykhiev R, Beisswenger C, Kändler K, Senske J, Püchner A Damm T, Behr J and Bals R: Human endogenous antibiotic LL-37 stimulates airway epithelial cell proliferation and wound closure. Am J Physiol Lung Cell Mol Physiol 289: L842-L848, 2005.

24. Pan G: Inhibitory effect of antimicrobial peptide LL-37 on bladder tumor cells (unpublished $\mathrm{PhD}$ thesis). Kunming Medical University, 2015

25. Ren SX, Shen J, Cheng AS, Lu L, Chan RL, Li ZJ, Wang XJ, Wong CC, Zhang L, Ng SS, et al: FK-16 Derived from the Anticancer Peptide LL-37 induces caspase-independent apoptosis and autophagic cell death in colon cancer cells. PLoS One 8: e63641, 2013.

26. Coffelt SB, Waterman RS, Florez L, Höner zu Bentrup K, Zwezdaryk KJ, Tomchuck SL, LaMarca HL, Danka ES, Morris CA and Scandurro AB: Ovarian cancers overexpress the antimicrobial protein hCAP-18 and its derivative LL-37 increases ovarian cancer cell proliferation and invasion. Int J Cancer 122: 1030-1039, 2008.

27. Kim JE, Kim HJ, Choi JM, Lee KH, Kim TY, Cho BK, Jung JY, Chung KY, Cho D and Park HJ: The antimicrobial peptide human cationic antimicrobial protein-18/cathelicidin LL-37 as a putative growth factor for malignant melanoma. Br J Dermatol 163 959-967, 2010.

28. Von Haussen J, Koczulla R, Shaykhiev R, Herr C, Pinkenburg O, Reimer D, Wiewrodt R, Biesterfeld S, Aigner A, Czubayko F and Bals R: The host defence peptide LL-37/hCAP-18 is a growth factor for lung cancer cells. Lung Cancer 59: 12-23, 2008.

29. Chieosilapatham P, Ikeda S, Ogawa H and Niyonsaba F: Tissue-specific regulation of innate immune responses by human cathelicidin LL-37. Curr Pharm Des 24: 1079-1091, 2018.

30. Ou Hongyu, Zhu Haihong, Zhu Wenjun, et al: Antimicrobial peptide LL-37 induces apoptosis in AGS cells of gastric cancer by activating p53 signaling pathway. J Anhui Med Uni 56: 571-576, 2021.

31. Vandamme D, Landuyt B, Luyten W and Schoofs L: A comprehensive summary of LL-37, the factotum human cathelicidin peptide. Cell Immunol 280: 22-35, 2012.

32. Wang G: Structures of Human host defense cathelicidin LL-37 and its smallest antimicrobial peptide KR-12 in lipid micelles. J Biol Chem 283: 32637-32643, 2008

33. Doss M, White MR, Tecle T and Hartshorn KL: Human defensins and LL-37 in mucosal immunity. J Leukoc Biol 87: 79-92, 2010.

34. An LL, Ma XT, Yang YH, Lin YM, Song YH and Wu KF: Marked reduction of LL-37/hCAP-18, an antimicrobial peptide, in patients with acute myeloid leukemia. Int J Hematol 81: 45-47, 2005.

35. Choi SY, Kim SJ, Chi BH, Kwon JK and Chang IH: Modulating the internalization of bacille calmette-guérin by cathelicidin in bladder cancer cells. Urology 85: 964.e7-964.e12, 2015.

36. Ang MK and Mok TSK: Twenty-five years of Respirology: Advances in lung cancer. Respirology 25: 26-31, 2020.

37. Xu N, Jia D, Chen W, Wang H, Liu F, Ge H, Zhu X, Song Y, Zhang X, Zhang D, et al: FoxM1 is associated with poor prognosis of non-small cell lung cancer patients through promoting tumor metastasis. PLoS One 8: e59412, 2013.
38. Xuan Y, Zhao S, Xiao X, Xiang L and Zheng HC: Inhibition of chaperone-mediated autophagy reduces tumor growth and metastasis and promotes drug sensitivity in colorectal cancer. Mol Med Rep 23: 360, 2021.

39. Wu WK, Sung JJ, To KF, Yu L, Li HT, Li ZJ, Chu KM, Yu J and Cho $\mathrm{CH}$ : The host defense peptide LL-37 activates the tumor-suppressing bone morphogenetic protein signaling via inhibition of proteasome in gastric cancer cells. J Cell Physiol 223: 178-186, 2010.

40. Murray NP, Aedo S, Fuentealba C, Salazar A, Reyes E, Lopez MA and Minzer S: Circulating prostate cells and bone marrow micro-metastasis and not treatment modality determine the risk and time to biochemical failure in low risk prostate cancer. Arch Esp Urol 72: 1000-1009, 2019 (In Spanish).

41. Sancar A, Lindsey-Boltz LA, Unsal-Kaçmaz K and Linn S: Molecular mechanisms of mammalian DNA repair and the DNA damage checkpoints. Annu Rev Biochem 73: 39-85, 2004.

42. Liu X, Li J, Huang L, Wang Y, Yang M, Tang M and Qiu T: Preparation and evaluation of MPEG-PCL polymeric nanoparticles against gastric cancer. J Wuhan Univ Technol-Mat Sci Edit 35: 1162-1168, 2021

43. Tian W, Li B, Zhang X, Dang W, Wang X, Tang H, Wang L, $\mathrm{Cao} \mathrm{H}$ and Chen T: Suppression of tumor invasion and migration in breast cancer cells following delivery of siRNA against Stat3 with the antimicrobial peptide PR 39. Oncol Rep 28: 1362-1368, 2012 .

44. Zhu M, Miao S, Zhou W, Elnesr SS, Dong X and Zou X: MAPK, $\mathrm{AKT} / \mathrm{FoxO} 3 \mathrm{a}$ and mTOR pathways are involved in cadmium regulating the cell cycle, proliferation and apoptosis of chicken follicular granulosa cells. Ecotoxicol Environ Saf 214: 112091, 2021.

45. Bartek J, Lukas C and Lukas J: Checking on DNA damage in S phase. Nat Rev Mol Cell Biol 5: 792-804, 2004.

46. Al-Ejeh F, Kumar R, Wiegmans A, Lakhani SR, Brown MP and Khanna KK: Harnessing the complexity of DNA-damage response pathways to improve cancer treatment outcomes. Oncogene 29: 6085-6098, 2010.

47. Campos A and Clemente-Blanco A: Cell cycle and DNA repair regulation in the damage response: Protein phosphatases take over the reins. Int J Mol Sci 21: 446, 2020.

48. Zeng Q: Expression of antimicrobial peptide LL-37 in urothelial carcinoma of the bladder. Kunming Medical University, 2015.

49. Su L, Xu G, Shen J, Tuo Y, Zhang X, Jia S, Chen Z and Su X: Anticancer bioactive peptide suppresses human gastric cancer growth through modulation of apoptosis and the cell cycle. Oncol Rep 23: 3-9, 2010.

50. Fink SL and Cookson BT: Apoptosis, pyroptosis, and necrosis: Mechanistic description of dead and dying eukaryotic cells. Infect Immun 73: 1907-1916, 2005.

51. Li Jun: Antimicrobial peptide 17BIPHE2 inhibits lung adenocarcinoma A549 cells and its mechanism. Ningxia Medical University, 2018.

52. Song J, Ham J, Hong T, Song G and Lim W: Fraxetin suppresses cell proliferation and induces apoptosis through mitochondria dysfunction in human hepatocellular carcinoma cell lines Huh7 and Hep3B. Pharmaceutics 13: 112, 2021.

53. Chuang KC, Chen FW, Tsai MH and Shieh JJ: EGR-1 plays a protective role in AMPK inhibitor compound C-induced apoptosis through ROS-induced ERK activation in skin cancer cells. Oncol Lett 21: 304, 2021

54. Schwartz GK and Shah MA: Targeting the cell cycle: A new approach to cancer therapy. J Clin Oncol 23: 9408-9421, 2006.

55. Dong Y, Yang Y, Wei Y, Gao Y, Jiang W, Wang G and Wang D: Facile synthetic nano-curcumin encapsulated Bio-fabricated nanoparticles induces ROS-mediated apoptosis and migration blocking of human lung cancer cells. Process Biochemistry 95: 91-98, 2020.

56. Hong Y, Sun Y, Rong X, Li D, Lu Y and Ji Y: Exosomes from adipose-derived stem cells attenuate UVB-induced apoptosis, ROS, and the $\mathrm{Ca}^{2+}$ level in HLEC cells. Exp Cell Res 396: 112321,2020

57. Wang CL, Liu C, Niu LL, Wang LR, Hou LH and Cao XH: Surfactin-induced apoptosis through ROS-ERS-Ca2+-ERK pathways in HepG2 cells. Cell Biochem Biophys 67: 1433-1439, 2013.

58. Kuriyama I, Miyazaki A, Tsuda Y, Yoshida H and Mizushina Y: Inhibitory effect of novel somatostatin peptide analogues on human cancer cell growth based on the selective inhibition of DNA polymerase $\beta$. Bioorg Med Chem 21: 403-411, 2013.

59. Cabrera Zapata LE, Bollo $M$ and Cambiasso MJ: Estradiol-mediated axogenesis of hypothalamic neurons requires ERK1/2 and ryanodine receptors-dependent intracellular $\mathrm{Ca}^{2+}$ rise in male rats. Front Cell Neurosci 13: 122, 2019. 
60. Adams JM and Cory S: The Bcl-2 protein family: Arbiters of cell survival. Science 281: 1322-1326, 1998.

61. Liu Y, et al: HSV-2 miR-H4-5p negatively regulates CDKL2 gene expression, blocking actinomycin D (ActD)-induced apoptosis in vero cells. Chin J Biochem Mol Bio 17: 9728-9735, 2015.

62. Desagher S and Martinou JC: Mitochondria as the central control point of apoptosis. Trends in Cell Biol 10: 369-377, 2000.

63. Wang M, Lu X, Dong X, Hao F, Liu Z, Ni G and Chen D: pERK1/2 silencing sensitizes pancreatic cancer BXPC-3 cell to gemcitabine-induced apoptosis via regulating Bax and $\mathrm{Bcl}-2$ expression. World J Surg Oncol 13: 66, 2015.
64. Wang Z, Xu Z, Niu Z, Liang B and Niu J: Epieriocalyxin A induces cell apoptosis through JNK and ERK1/2 signaling pathways in colon cancer cells. Cell Biochem Biophys 73: 559-564, 2015.

(i) $€$ This work is licensed under a Creative Commons cc) Attribution-NonCommercial-NoDerivatives 4.0 International (CC BY-NC-ND 4.0) License. 